

INDEPENDENT JOINT ANTI-CORRUPTION

Monitoring And Evaluation Committee

\title{
REPORT OF THE PUBLIC INQUIRY INTO
}

\section{LAND USURPATION}

(Translated from Dari) 


\section{Acronyms}

\begin{tabular}{|c|c|}
\hline AMLK & Department of Land Affairs \\
\hline AGO & Attorney General's Office \\
\hline AGCHO & Afghanistan Geodesy and Cartography Head Office \\
\hline AMLAK & Land Management Bureau \\
\hline ARAZI & Afghanistan Land Authority \\
\hline AREU & Afghanistan Research and Evaluation Unit \\
\hline CCM & Commission for Conflict Mitigation \\
\hline CSO & Central Statistics Organisation \\
\hline DoA & Department of Agriculture, Irrigation and Livestock \\
\hline GoA & Government of Afghanistan \\
\hline GPS & Global Positioning System \\
\hline $\mathrm{HOO}$ & High Office of Oversight and Anti-Corruption \\
\hline IDP & Internally Displaced Person \\
\hline IDLG & Independent Directorate of Local Governance \\
\hline ICLA & Information Counselling and Legal Assistance of NRC \\
\hline LAC & Land Allocation Commission \\
\hline LARA & Land Reform in Afghanistan \\
\hline LAS & Land Allocation Scheme \\
\hline LAMP & Land Administration and Management Program \\
\hline MAIL & Ministry of Agriculture, Irrigation and Livestock \\
\hline MEC & $\begin{array}{l}\text { Independent Joint Anti- Corruption Monitoring and Evaluation } \\
\text { Committee }\end{array}$ \\
\hline MoHRA & Ministry of Haj and Religious Affairs \\
\hline Mol & Ministry of Interior \\
\hline MoF & Ministry of Finance \\
\hline MoJ & Ministry of Justice \\
\hline MoLSAMD & Ministry of Labor and Social Affairs \\
\hline
\end{tabular}




\begin{tabular}{ll} 
MoRR & Ministry of Refugees and Repatriation \\
MoWA & Ministry of Woman`s Affairs \\
MP & Member of Parliament \\
NRC & Norwegian Refugee Council \\
NGO & Non-Governmental Organization \\
OAA & Office of Administrative Affairs \\
PTRO & Peace Training and Research Organization \\
TLO & The Liaison Office \\
UN & United Nations \\
UNAMA & United Nations Assistance Mission in Afghanistan \\
UNDP & United Nations Development Programme \\
UNEP & United Nations Environment Programme \\
UN- HABITAT & United Nations Human Settlements Programme \\
UNHCR & United Nations High Commissioner of Refugees \\
USAID & United States Agency for International Development \\
USIP & United States Institute for Peace \\
VRF & Voluntary Repatriation Form \\
WFP & World Food Programme \\
\hline
\end{tabular}




\section{Message from the Committee}

Land usurpation has affected the lives of hundreds of thousands of Afghans over the decades.

Afghanistan's history is one of political instability, which has contributed to the problem of ineffective land administration. Wars and the migration of millions of people have created significant displaced populations throughout the country. Various factors, such as the lack of a comprehensive land survey and survey documents, have also exacerbated the problems of land administration. Land in urban areas and quality agricultural land are especially vulnerable to usurpation, with influential groups and people appearing to take advantage of weaknesses in the system.

Despite the importance of the land usurpation issue in Afghanistan, there has not been a comprehensive report on the matter. Nor have there been integrated efforts to identify the steps required to ensure that land usurpation is eliminated and that violators are held responsible for their actions.

MEC's Report of the Public Inquiry into Land Usurpation is intended to provide a comprehensive review of the surveying, registration, transfer, and distribution of land in Afghanistan and to describe formal and informal dispute resolution procedures. It identifies the challenges facing the relevant entities and provides practical recommendations to mitigate the risk of land usurpation in the future. Many recommendations included herein are indicative of broader systematic challenges to good governance, effective administration, and justice in Afghanistan.

Sincerely on behalf of MEC,

M.Yasin Osmani, Chair

MEC 


\section{Acknowledgements}

Preparing a comprehensive report on land usurpation is a complex and technical task. The public inquiry into land usurpation was carried out with the extensive support from the MEC Secretariat, including international and national lawyers, all of whom played an essential role in developing the report.

The significant cooperation of relevant agencies and institutions at different stages of this research was also essential. These included:

- Directorate of Cadaster Survey

- Kabul Primary Courts

- Kabul Archive

- MoJ's Department of Legal Rights

- $\operatorname{MoRR}$

- $\quad$ ARAZI

- $\mathrm{MOI}$

- Ministry of Haj and Religious Affairs

- $\quad$ AGO and other judicial instiutions

MEC acknowledges the cooperation of all individuals, departments, and institutions who assisted us, regardless of whether their names are mentioned here. Unfortunately, MEC made great efforts to obtain detailed statistics concerning the distribution of lands by Kabul Municipality, but, despite repeated requests, they refused to share the requested information. 


\section{Table of Contents}

Acronyms

Message from the Committee

Acknowledgements

Table of Contents

Executive Summary

I. Introduction

II. Methods and Sources

III. Overview of Historical and Current Land Administration

1.) Brief historical overview of land administration in Afghanistan

2.) Brief overview of current land-management authorities 15

a.) ARAZI

b.) Courts

c.) Municipalities 15

d.) Ministry of Justice 15

e.) Ministry of Finance 15

f.) Ministry of Agriculture, Irrigation and Livestock

f.) Ministry of Agriculture, Irrigation and Livestock

IV. Land Surveys in Afghanistan 16

1.) Past efforts to survey land in Afghanistan 16

2.) Contemporary efforts to survey land 16

3.) General surveying procedures 17

4.) Current challenges in the surveying process 18

V. Land Registration 19

1.) The importance of land registration 19

2.) Land registration procedures of distributed lands 19

VI. Land Transfer 20

1.) Transfer of private land 20

2.) The Repository (Makhzan) of deeds 22

3.) Challenges and usurpation within the land transfer procedure 22

4.) Methods of land usurpation 23

5.) Transfer of governmental land 24

VII. Land Distribution 25 
1.) Land distribution by Kabul Municipality ___ 25
a.) Distribution based on eligibility
b.) Distribution as compensation for expropriated land___ 26
c.) Distribution of land for commercial sites _ $\quad 27$
d.) Methods of land usurpation within Kabul Municipality___ 27

2.) Land distribution by MoRR _ 28

a.) Methods of usurpation in the MoRR townships__ 28

3.) Endowed Lands of the Ministry of Haj and Religious Affairs $\quad 29$

VIII. Formal Dispute Resolution___ 30

1.) Addressing land usurpation cases through the Department of Legal Rights (Huquq)___ 30

2.) Dispute resolution procedures initiated by the Huquq Department

a.) Administrative steps __. 30

b.) Investigation and acquisition of rights __.) Chatlenges to the resolution of disputes within the Huqua 31

c.) Challenges to the resolution of disputes within the Huquq _ 32

d.) Procedures at the courts__ 32

e.) Adoption and enforcement of court orders __ 33

f.) Challenges within the formal judiciary __ 34

3.) Governmental Land Cases ___ 35

a.) Court procedures regarding governmental land ___ 35

b.) Challenges related to the Department of Government Cases___ 36

IX. Informal Dispute Resolution __ 36

1.) Informal dispute resolution in Afghanistan ___ 36

2.) Procedures within Shuras and Jirgas___ 37

3.) Challenges of the Informal Dispute Resolution Process __ 38

X. Land Usurpation in the Provinces ___ 38

1.) Balkh Province

2.) Herat Province

3.) Nangarhar Province $\_40$

4.) Kapisa Province __ 41

5.) Challenges of land usurpation throughout Afghanistan

XI. Efforts to Tackle Land Usurpation ___ 41

1.) Legislative Initiatives __ 41

2.) Efforts of the National Assembly___ 42

3.) Government Bodies _ـ 43
a.) MAIL and ARAZI
b.) $\mathrm{MOI}, \mathrm{AGO}, \mathrm{HOO}$
c.) Establishment of the Special Commission of Urban Properties and Townships Usurpation___ 44
d.) Actions taken through Land Allocation Schemes (LAS) __ 45 
4.) Actions taken by Civil Society Organizations

5.) Actions taken by the international community

6.) Role of media in the fight against land usurpation

XII. Conclusion

XIII. Recommendations 47

Annex I: Terms of Reference for the Report on the Public Inquiry on Land Usurpation

Establishment of the Public Inquiry

Mandate 49

Procedures 50

Resources 50

Annex II: Sources Considered by the Committee 51

Annex III: Data on Usurped Land in Afghanistan 53

1.) Table of illegal townships and residential areas 53

2.) Land usurped by government organisations according to provinces 53

3.) Usurped governmental lands across the country 53 


\section{Executive Summary}

\section{Historical and contemporary factors have contributed to the scope of the land usurpation problem in Afghanistan}

The usurpation of state and private land has been a significant problem for the government and people of Afghanistan over the past ten years, with statistics compiled by ARAZI indicating that more than 1.2 million Jeribs ${ }^{1}$ of land have been usurped during the past decade.

The roots of the problem are historical, including settlement policies in specific areas at the end of the $19^{\text {th }}$ century, the settlement of nomads and land registration policies during the time of King Zahir Shah, the land-reform policy during Daud Khan's regime, land policies imposed during the communist era, and the ravages that took place at the time of Mujahedeen and Taliban. Wars, ethnic conflict, and the lack of a unified and strong central government have also been among the factors contributing to the problem in the past decades.

However, in recent years, widespread corruption, insecurity in some parts of the country, the lack of a unified land administration system, weak police and law enforcement units, the extensive presence of warlords, the lack of land registration and surveying, and the absence of adequate legal provisions have played an important role in spread of this problem.

\section{Only 1/3 of land in Afghanistan has been surveyed and registered}

Since its establishment, the Directorate of Cadastral Survey has conducted several surveys during which only $34 \%$ of all land has been surveyed and registered. The lack of a survey and registration of $66 \%$ of land provides the chance for land usurpation, since the survey and registration of lands has a very basic role in preventing usurpation and identifying usurpers. Another point of concern is the vulnerability of survey methods. According to interviewees, it is possible that the land/property of a person can be registered in the name of another person during the survey, or that a person's land-survey record is destroyed after the survey to facilitate the usurpation of the land at a later date.

\section{A Number of issues lead to vulnerabilities in the registration process}

In the process of land registration, there are serious vulnerabilities that have provided possibilities for land usurpation. These mostly relate to the primary and appeal courts, as it appears that documents and deeds are being removed or replaced with fake deeds in Makhzans, which is a common type of usurpation through courts. Additionally, land is usurped by forging powers of attorney, customary land deeds, and inheritance. There are also problems associated with the storage of files, as the low quality of paper makes them susceptible to deterioration due to humidity. The insecurity of deeds in the database, as well as in hard-copy form, put them at risk of disappearing.

\section{Courts are seen by many as a center of corruption}

\footnotetext{
${ }^{1} 1$ Jerib $=2000 \mathrm{~m}^{2} / 0.2$ hectare
} 
Forging official deeds by court employees appears to be one of the main methods of land usurpation. The Department of Cadaster Survey facilitates these opportunities in relation to state lands. Interviews indicate that employees - particularly in Balkh province - allow usurpers to access information concerning government-related arid land and wastelands that are not registered in the department. It has also been reported that some staff members have burned land-registry offices intentionally. There are some cases where the court had made decisions for the benefit of one person during the land claim, but after being informed of investigations, they nullified their judgment to conceal misconduct. Unfortunately, it has been reported that staff and judges who fight land usurpation, and do not take part in unlawful activities, are transferred from their posts and, in some cases, were fired.

\section{Land distribution through municipalities is vulnerable to corruption}

The process of land distribution in municipalities takes place in three forms, land-entitlement distribution, acquisition, and distribution of commercial areas. Non-eligible individuals appear to have taken lands based on orders of high ranking government officials. Furthermore, the forgery of documents and the signatures of high ranking officials, inserting additional names on the eligibility list of the land distribution commission, providing false, and changing the land registry are among the main methods of land usurpation at the municipal level. Occupation of municipal lands by governmental organizations, especially the $\mathrm{MOI}$, is another concern. Some commercial areas are transferred to specific people and municipal employees have reportedly been receiving bribes to modify the value of expropriated land and in the allocation of land meant to compensate meant for that expropriation.

\section{Land deeds are being distributed without the actual distribution of the associated lands}

The evaluation of the distribution process in Kabul Municipality shows that this institution has handed over 42,000 deeds without distributing the lands with them. The Municipality has been able to distribute land for only 4,000 deeds. Satisfying influential people, the lack of insufficient tracking of available land, and the existence of widespread corruption appear to be the main causes of this issue. According to municipal officials, this problem started during the time of Najibullah's government (1987-1992).

\section{Refugee settlements are vulnerable to unlawful actions by powerful individuals}

MoRR has distributed more than 68,426 plots of land in 62 towns across the country. Among the issues that interfere with the settlement of repatriates are: orders from high ranking government officials, forgery of the Voluntary Repatriation Form, fake property deeds and taxation documents, and the misuse of customary deeds where the area of land is not specified.

\section{Cemetery and mosque land has been usurped}

The Ministry of Haj and Religious Affairs is responsible for lands and property endowed to it in trust. According to the latest report, 49,743 Jeribs are under the Ministry's tutelage. Of this, MOHRA has reported that approximately 32,838 Jeribs have been usurped by powerful people and government institutions. Cemetery lands contain the largest part of usurped endowment lands. There are instances that show mosque lands are also usurped by people. 
The absence of a register and survey of endowment lands facilitate the usurpation of these lands.

\section{Review in Balkh province reveals various methods of land usurpation}

The findings in Balkh show that land usurpation has roots in the early 1970s and 1980s. During this period, portions of land were distributed to the supporters of political parties, resulting in many of them possessing "party related deeds" when a specific party was in power. In addition, lands have been usurped through property dealers' offices. The lands usurped through property dealers are mostly related to absentee landowners. Individuals or groups claiming to have ownership deeds from the late 1960 s to the early 1970 s change the figures in documents by adding a number/figure in the document.

\section{Forgery and misuse of customary deeds in Herat}

In Herat, one of the issues is the existence of unclear land descriptions in customary deeds. A person, by misusing customary deeds, claims that his part of the property is "from this to that mountain." Forgeries of powers of attorney, inheritance documents, and removing the heirs from the documents are among the main ways that state and private lands have been usurped in Herat. However, there is also a land shortage in Herat municipality, exacerbated by the issuance of deeds to one parcel of land to many individuals.

\section{Land leasing raises concern in Nangarhar}

The history of land usurpation in Nangarhar is connected to the communist regime. Techniques of land grabbing are similar to other provinces and include forging powers of attorney, inheritance documents, customary documents, legal deeds, government orders, as well as the misuse of power by influential individuals and groups. In addition, the widespread presence of warlords has become a serious concern, and some government agencies, such as AISA, are causing problems, as they distribute land before the legal land-transfer procedure is complete.

\section{Formal and informal mechanisms exist for the resolution of land disputes}

Land dispute resolution methods differ according to whether the dispute is between individuals and the government, between government entities, or between individuals. Disputes between government entities or a private and a government entity, are resolved through the Office of Government Cases before being referred to the courts. Disputes between individuals are addressed through the Department of Legal Rights, and in case of no agreement, processed through the formal judicial procedure. Disputes are also sometimes addressed through informal dispute resolution by Shuras and Jirgas.

Actions by the government have not had a major impact on resolving land usurpation issues

During the last decade, there have been many obstacles to fighting land usurpation. It appears that there has been no political will, insufficient legal provisions to prosecute usurpers, and a lack of security in some parts of the country. 
The government has taken some steps to fight land usurpation, including the issuance of Presidential Decree 45 (2012), the drafting of the Law on Usurpation and Illegal Occupation of State and Private Lands, the establishment of ARAZI, and preparation of a comprehensive Report on Land Grabbing by a special commission of the Wolesi Jirga. The judicial system, government and other agencies have also taken some steps to tackle land usurpation, such as the establishment of special courts and provincial committees, but they have not comprehensively addressed the issue. 


\section{Introduction}

The usurpation of state-owned and private properties, estates, and land has been one of the major problems facing the Afghan government and the public during the past 10 years. Although the roots of the problem go far back in the history of Afghanistan, the problem has become bigger in the last decade, with ARAZI showing the usurpation of $1,200,000$ Jeribs of land over the last 10 years.

Land usurpation is occurring from a variety of sources from powerful individuals to impoverished squatters. There are various factors leading to land usurpation, including long wars, tribal conflict, and lack of effective government administration. Many interviewees have identified the poor security situation, the movement of people towards cities, and the lack of political determination to resolve the issue as contributing to land usurpation. Other factors, such as the inability to implement a land management system and insufficient regulations, have also played a large role.

Although there are some laws regarding land usurpation, they enforced on an ad hoc basis and do not represent a comprehensive approach to deter and punish land usurpers. The Penal Code of Afghanistan indicates that public officials using their official authority to forcefully buy an immovable good, or illegally turning it into their own property or forcing the owner to sell to someone else, will be sentenced to imprisonment of not more than two years and a cash fine of not more 24,000 Afghanis. This provision, however, only deals with forcefully bought property and is only applicable to public officials, leaving significant gaps.

The new Land Management Law is currently being drafted by MoJ, and the Land Grabbing Law was recently passed by the National Assembly, but amendments were made by the President and it was sent back to the National Assembly for further discussions. The latter law outlines specific criminal charges for land usurpers, as well as has detailed provisions on the administrative proceduresf or returning land to its proper owner.

Afghanistan seriously depends on agriculture and land issues should be of the highest priority, but the lack of decisiveness and political will to address the issue has made people think that the government is unwilling or unable to take action.

ARAZI was established in 2012, with the main purpose of managing land related issues in the country. Later, the Cadaster Department was merged with ARAZI for better coordination. The achievements of ARAZI in recovering pieces of state-owned land are to be acknowledged, but the entity is facing a lack of sufficient resources to carry out its assigned tasks. ARAZI is responsible for collecting information pertaining government land, however there is no entity responsible for collecting information of private land and maintain it in a comprehensive database accessible to the public. Besides that, the varieties of customary documents for lands, which have no official title, make the process more complicated.

This public inquiry assesses the procedures of land survey, registration, transfer, distribution, and dispute resolution to identify vulnerabilities to corruption and poor administration. The report identifies types of land usurpation, as well as the sufficiency of governmental approaches and responses. Recommendations and strategies are proposed based on the findings. 


\section{Methods and Sources}

The public inquiry into land usurpation was undertaken by MEC, supported extensively by the Committee's Secretariat in Kabul which was responsible for administrating all aspect of the inquiry.

The first stage of research involved the collection of reports related to land administration and usurpation published by various institutions. The second phase of research included collecting laws, regulations, decrees, and administrative procedures from different organizations. The regulatory framework governing the land sector in Afghanistan is complex and consists of statutory, customary, and Islamic jurisprudence law. The main legislative texts relating to land issues include the Civil Code, and the Law on the Acquisition of Rights, which contain hundreds of provisions regarding land and property rights, as well as various regulations and Presidential Decrees, such as PD 45 and PD 104. The proposed Land Management Law, as well as the Law on Grabbing and Illegal Occupation of State Owned and Private Land, will if implemented, introduce penalties and criminal charges for land usurpers. The third phase involved the collection of official documents. In the fourth phase, interviews with key persons were conducted. Finally, MEC attempted to conduct interviews with members of the public to include their point of view.

\section{Overview of Historical and Current Land Administration}

\section{1.) Brief historical overview of land administration in Afghanistan}

Different regimes in Afghanistan have introduced land reforms in the past without being able to fully implement their policies. Under the monarchy and previous governments, the assignment of privileges to specific groups loyal to leadership was a common practice. Different policies gave rise to tribal conflicts over land in various parts of country triggering wars between tribes in respective areas of the country. Undoubtedly, changes in land policies paved the way for conflict, violence, and revenge up to today.

A survey and registration was conducted by King Zahir from 1960-1970, which was supported by USAID, but this policy was ultimately abandoned as result of the April 1978 revolution. Following that, the first president of Afghanistan, Daoud Khan started the implementation of a policy on land reform until 1978. According to a land decree issued in 1978 , the aim of the policy was to put an end to feudalism and get rid of different castes. No family had the right to possess more than 30 Jeribs of first-class land or its equivalent. Compensation was not paid for the expropriation of surplus land, which was distributed through a public lottery. Land registration was mandatory at this time. Individuals who misrepresented the size of their property by more than $20 \%$ lost an equivalent portion of their property to the government.

In 1987, after the fall of the Communist regime, the Constitution stipulated that all forms of lawful properties were protected and that state, mixed, cooperative, trust lands, and private property, as well as properties of political and social organizations, were allowed to exist. However, regardless of recognition, there was extensive damage caused by the occupation and war, with more than half a million houses being destroyed. 
In 1990, a new decree was issued to compensate owners for land that could not be returned. However, in 1992, during the time of the Mujahedeen in Afghanistan, an unprecedented crisis erupted affecting the land, as no farmer or field was safe. Properties came under attack, and houses were built across cities outside of official plans. Every area was fighting for their interest and conflicts were building up amongst families.

Relative peace and order prevailed in some parts of country for a time after the Taliban came to power in 1996. Supporters of the Taliban tried to regain possession of their lands and, in some instance,s retaliation transformed land-related issues into open conflicts.

\section{2.) Brief overview of current land-management authorities}

There is no single organization responsible for land management in Afghanistan. The direct and indirect involvement of different organizations complicates the administration of land, leading to chaotic working processes and poor coordination. During interviews, some organizations inappropriately delegated or ignored their responsibilities.

\section{a.) ARAZI}

The Afghanistan Land Authority was initially established within the frame of MAIL to administer the leasing of governmental land by leasing it to investors who request land for their business activities. According to a Council of Ministers' resolution of 2010 this entity was merged with the general directorate of properties and land regulatory of MAIL and became an independent organization.

The Cadaster Survey Department operates under the Afghan Geodesy and Cartography Office that was later merged with ARAZI. The Department was established in 1963 by the Cadastral Survey Law to conduct surveys of all private and state-owned lands. Surveys by the Cadaster Survey Department are carried out for specific purposes, such as mapping for property records and to better manage tax affairs in the country, as well as for distinguishing personal properties from state owned lands.

\section{b.) Courts}

The land management system in Afghanistan is generally governed by the courts. Primary and appellate courts play a crucial role in preparing and managing legal land documents and deciding land-related cases. There is one appellate court in the provincial centers of most provinces and one primary court in each district center to address issues related to land disputes.

\section{c.) Municipalities}

Land distribution is the main responsibility of the municipalities in Afghanistan. There are generally three types of land distribution based on eligibility, as compensation for expropriated land, and commercial plots. This study reviewed the procedures of Kabul Municipality as an example of municipal land distribution in Afghanistan.

\section{d.) Ministry of Justice}

MoJ contains the departments of the Huquq and Government Cases. As stated in the Rights Restoration Act, the Department of the Huquq has responsibility to restore the rights of claimants whose property has been usurped. The department is the first institution where civil cases, including cases of land usurpation, are resolved. 
The Department of Government Cases is the official authorized body that represents the government in civil cases. Since the Civil Law considers land usurpation a civil matter, the Department of Government Cases initiates lawsuits in instances where state-owned land has been usurped.

\section{e.) Ministry of Finance}

The MoF plays a role in the registration and transfer of lands as it, according to its administrative and legal procedures, determines the value of the land for tax purposes.

\section{f.) Ministry of Agriculture, Irrigation and Livestock}

All agricultural land is managed by MAIL and all quantitative and qualitative data and figures on such land are recorded with MAIL.

\section{Land Surveys in Afghanistan}

Land surveys form the foundation of effective land administration in any country and allow property boundaries and ownership to be more easily identified making it possible to identify land usurpers. However, there has not been a complete survey of land completed in Afghanistan, and much reliance is put on the partial surveys conducted between 1965 and 1978.

\section{1.) Past efforts to survey land in Afghanistan}

The first survey in the history of Afghanistan was conducted by the MoF in order to determine tax rates for land - and for property owners. Subsequently, several surveys were conducted with the main purpose of distinguishing private lands from government and public lands. For example, from 1965 to 1978, the national program of land registration mapped and registered $45 \%$ of the agricultural land in 5,502 offices. Within this period, $33 \%$ of state, individual, agricultural, and non-agricultural land was surveyed. After 1978 the government undertook its "land reform policy," the aforementioned survey was replaced by the land distribution program within the Cadaster Department within limiting its mandate to land distribution.

No land survey was carried out during the Taliban's rule, and the Cadaster Survey Department was only providing information and services to the public and the government. Presidential decree 83 from 2003 prohibited any new surveys to be conducted without presidential order.

\section{2.) Contemporary efforts to survey land}

There is currently no comprehensive initiative to survey land in Afghanistan. Specific surveys have been mandated by specific presidential decrees in order to launch development projects. However, even some of these surveys could not be carried out due to various problems. For example, a presidential decree was issued regarding the survey of the Ash Poshtam area in Bamyan province, which was related to MOMP, but sending the survey team to the site was not possible and the relevant institutions and officials did not cooperate. Therefore, the presidential decree could not be enacted and the survey was not carried out. 
According to handbook on land law published by USAID in 2013, 115,962,670 Jeribs (89\%) of Afghanistan is state-owned land, and around 15,054,306 Jeribs (11\%) belongs to individuals.

According to figures from the Cadaster and Survey Department, the total amount of agricultural land adds up to around 44.5 million Jeribs countrywide. Approximately $34 \%$ of these lands have been surveyed from 1965 to the present. Of this amount, approximately 12 million Jeribs belongs to individuals, around 2.5 million Jeribs is state-owned agricultural land, and 13 million Jeribs is non-agricultural land. When added with the $1 \%$ of land $(620,000$ Jeribs) surveyed after 2003 , the land surveyed in total so far is approximately 28 million Jeribs, which adds up to about one-third of all land in Afghanistan.

\section{3.) General surveying procedures}

The accuracy of land specifications is the responsibility of the Cadaster survey team. The team is responsible for the accuracy, measurement, and demarcation of the area of each piece of land and other qualitative and quantitative details. When its directorate wants to survey an area, it informs the population of the area at least 15 days before the beginning of the survey. Residents or owners in the area have obligations to assist the team and be present during the survey, accompanied by community partners and neighbors.

The survey team is obliged to survey the specifications of land according to the characteristics told by the land owner, neighbors, and representatives of the community. At the end of the survey the team shares its results with the villagers and a copy of the map and a list of owners for each parcel of land is posted in a location in the village visible to the public.

\section{The absence of the land owner can lead to false documentation}

The law stipulates that the owner of the surveyed land shall be present. If he cannot be present at the specified time, the land will be surveyed according to statements provided by the farmer of the land, villagers, and two neighbors. It has been reported that this requirement leaves the process susceptible to collusion between a farmer and neighbors who provide the survey team with incorrect information. This is particularly problematic, as the survey documents could become evidence in land disputes at a later date.

In cases in which a Cadaster survey is not possible or has not been carried out, the law proposes other methods, such as surveying by using aerial photo sketches, direct measurements, topographic maps, and engineering, and technical surveys. These surveys can be carried out by the relevant administration upon the agreement of the cartography administration or the agreement of $\mathrm{MoD}$ and $\mathrm{MOI}$, if the parcels of land are located in prohibited areas.

\section{Complaint procedures include traditional and formal dispute resolution}

Complaints regarding the survey can be addressed to the Cadaster committee by submitting a written objection within one month of the survey's announcement. The Cadaster committee 
engages in resolving the objections in the presence of village representatives, neighbors, and local water managers ${ }^{2}$.

If the complainants are still not satisfied, they may submit the case to the courts, which are obliged to issue a decision within one month and inform the Cadaster survey team about the results. Upon the rendering of a decision by the court, the maps and lists containing the names of landlords shall be amended, stamped, and signed by the Cadaster committee.

\section{Topographical surveys is now under supervision of ARAZI}

Before the Geodesy and Cartography Department merged with ARAZI, topographical surveys were carried out by ARAZI using GPS techniques. Officials of ARAZI have indicated that the surveys were intended to protect unutilized governmental lands from usurpation. After the unification of the Geodesy and Cartography Department with ARAZI, this task is now performed by the Cadaster Department.

\section{4.) Current challenges in the surveying process}

Multiple sources have indicated that land usurpation is possible throughout the survey process. Although the maps in the Cadaster Department cannot be changed, names of land owners can be changed in the original documents later on. This is possible due to the lack of secure hardware and software being used by the authorities.

Cadaster officials have noted that the lack of security and stability throughout the country is one of their biggest challenges, making the survey process impossible to carry out in many parts of the country.

Another problem that Cadaster officials mentioned is the lack of cooperation from land owners during surveying. It has been reported that internal disputes and the fear of taxation are the main reasons. The lack of cooperation extends to other individuals that have a role in the process, for example, land shareholders, head of local councils, and elders in the area.

Finally, Cadaster has a very small organizational structure. This problem has caused the Directorate to have limited success in conducting larger surveys that require more employees. Officials believe that local and emergency surveys do not need a lot of people, but cadastral surveys require a significant facilities and staff. Despite the use of new technology, the law calls for "on site" visits and with the low number of technical staff, it is doubtful that the department can work efficiently. According to officials, most of Cadaster employees are close to retirement. From 1966 to 1979, the number of members of the department reached 1,800, but was reduced significantly in the Taliban era and now only numbers only 180 employees. This lack of human resources raises concerns about the effectiveness of the office.

\footnotetext{
${ }^{2}$ Local water managers are responsible to distribute and manage water distribution to the farmers.
} 


\section{Land Registration}

\section{1.) The importance of land registration}

Land registration protects proprietary rights, facilitate land transfers, and enables land to be used as a guarantee for loans. Currently, land-registration procedures in Afghanistan must be done through the courts in the provinces and through the Documentation Department in Kabul in order to receive legal title. When a person has gone through the land distribution or transfer procedure and has received land from the municipality or any other source, he is then entitled to receive a formal deed for the property.

\section{2.) Land registration procedures of distributed lands}

In Afghanistan, the land-registration process requires numerous administrative steps in which the land owner is required to fulfill certain requirements and present related evidence. The land registration procedure is a very long process involving various departments and is vulnerable to corruption, as land owners often try to speed up the process through bribery.

\section{A case study: Land provided by Kabul Municipality}

In the first step, a person has to submit his petition to the organization from which he has received the land. Taking Kabul Municipality as a model, the recipient shall submit a petition to get the land registered to the Kabul Municipality.

The Municipality, after assessing the petition, will forward it to the Properties Department. The Properties Department of the Municipality will refer the petition to the Revenue Collection Directorate to ensure a proper ownership record of the land. The Revenue Collection Directorate will then send the petition to the Land Distribution Directorate to report on the primary characteristics of the land, such as water access and agricultural qualities.

After receiving response, the Revenue Collection Directorate will forward the petition to the Directorate of the Urban District to ensure that the land and property are registered in the name of the person. Second, the price paid for the land has to be rechecked. Third, the boundaries of the land have to be verified according to the documents and the new owner has to prove that he has started with the construction of living facilities and completed at least $40 \%$ of latter.

The Plan and Implementation Department of Kabul Municipality will assesses the listed requirements and forward the case to the Revenue Collection Department. The Revenue Collection Department will forward it with a detailed letter checked and stamped by the Head of Properties Department to the Office of the Kabul Governor, attaching a copy of the land title deed, the National ID, the power of attorney (if he is representing someone), and a referee's petition.

In addition to the above, the Municipality letter will include all characteristics of the land, including location, boundaries, length and width, cost, and a bank slip indicating the payment of money. Finally, when the court or Documentation Department receives the documents from Kabul Province, they insert the information into a formal deed prepared for the owner. 


\section{Land Transfer}

\section{1.) Transfer of private land}

\section{Courts are obliged to verify the legality of land documents before land can be transferred}

Whenever the owner of land included in the official map wants to transfer his land to another person, the authorized court is obliged to seek the endorsement of the property office concerning the number of Jeribs, boundaries, and other specifications prior to the preparation of legal documents or transfer. The court shall also send a report about the means for transferring the ownership to the relevant Cadaster administration upon the issuance of legal documents so that data may be amended in the maps and lists of the survey. Prior to this, the Primary Court reviews the list of banned properties to ensure that it is not a prohibited property.

\section{The registration process is carried out through circular forms}

Subsequently, the Primary Court hands out two circular forms to the applicant to be processed for the verification of the property and approval by the Supreme Court. The individual is obliged to process both forms simultaneously. One copy of the official ownership document is given to the person and the other, attached with a copy of the official ownership document, is stored in the repository. In addition, the basic information from the form, including seller and buyer identification, landlord, date and taxes, is recorded in a book called the "Heir Book."

The judicial organ inquires about the existence of an individual property deed in Makhzan and its exact specifications. After that, the circular form is referred to the District and Municipal Property Management Units to certify the estate of the individual property, and provide information about its location, area, and value.

Although seller and buyer agree on a price, the Municipality appraises the amount in order to ensure a fair market price and to prevent unlawful pricing agreements. A price check is prepared by the Municipality and a special pricing commission comments on the quality of the property according to the market price. The pricing commission is based in Kabul Municipality and only works on specific days (Sundays and Tuesdays), therefore contacting them is challenging. The Directorate of Revenues of MoF, besides being a member of the pricing commission, enforces a $1 \%$ tax on the transaction price. After the tax is paid, oversight of two other offices in the circular form is necessary: the Cadaster Directorate and the Ministry of Agriculture.

\section{Circular forms did not include any Cadaster verification in the past, allowing for fraud}

Circular forms did not specify which land from the Cadaster map was being sold in transfers taking place before a presidential decree was issued in 2004 requiring this information to be included. According to an employee of this department, however, the column for this information was again removed for unknown reasons. In 2008, this column was re-added in the form by the instruction of the First Vice President. Based on this, regional employees of 
the Directorate of Cadaster Surveys now check the properties that are supposed to be sold within cadastral maps.

\section{Additional review is required if the land has been mapped}

After verification of the department of AMLAK of MoF, a Cadaster team reviews the land being sold to compare it to the map. The purpose of this additional verification is to verify land and ownership and avoid any disputes between the owner and neighbors. In the event of a discrepancy, the matter will be highlighted in a circular form to the primary court. In the case of no contradictions, approval is given in the Cadaster column that the piece of land then belongs to a certain person.

After the circular form goes through the aforementioned steps, it is referred to the Head of the Court or Department of Document Registration for final approval. After proceeding through the necessary steps, the deed is prepared and sent to the related district office where the process is completed. The deed consists of two parts, the body, which is given to the customer, and the core, which is maintained and filed with the court and delivered to the repositories. Between March and November 2013, about 500 circular forms have been referred to the Cadaster Department.

\section{Concerns must be raised about the duration of the registration process}

While the Primary Court estimates the time spent on registration to be a maximum 15 days, some sources have estimated the time for property registration is more than two months, with at least $50 \%$ of this time allocated to the primary court.

The duration of the process appears to rely on the initiative and effort of the applicant in preparing and submitting documents. According to information received from the courts, the internal processing only requires two days: the day the petition is submitted and the day the applicant receives the deed. Court officials have indicated that it takes the courts just a couple days to get their work done, coordinating with the other organizations, because liens are stored in a computerized system now and they receive results quickly.

It appears that the comprehensive cross-checking mechanism of different authorities and onsight surveys are attempts to decrease fraudulent actions. The documentation through the circular form allows a transparent tracking of the process.

\section{Agricultural land involves additional verification procedures before it may be transferred}

The transfer of agricultural land involves different entities. MAIL is the primary agency involved in land settlement and related issues. Furthermore, the Supreme Court, MAIL, MoF, MoEW, the Department of Geodesy and Cartography, and local authorities have the responsibility to implement the requirements of the land-settlement procedures, whereby the practical work in the area will be conducted by the land settlement delegation.

The Land Management Law outlines the responsibilities and authorities of the settlement/clearance delegation. Land settlement is a procedure for agricultural land in which the specifications of a piece of land (location, borders, area, size of the water rights, etc.) are defined. The purpose of the land-settlement procedure is to ensure that the 
property does not belong to any other person, is not subject to a lawsuit, and is not government property. The results are sent to the local land and tax-register offices to be registered in the related books and legal documents are then prepared. Conflicts and disputes concerning land, if not solved by the settlement delegation, will be returned to court in order to resolve them. In the case of land being illegally distributed in the past, the law contains restoration provisions.

\section{2.) The Repository (Makhzan) of deeds}

Transferring land includes the formal documentation of the ownership transfer. In all provinces, documents are stored under the supervision of the provincial court of appeals, which preserves more than 24 types of legal liens, including land title deeds. The storage facilities in these provinces do not have a particular Tashkil, and are being led by an acting director appointed by the head of the appeals court.

Every document issued by the court must be kept in the storage. When registry books are filled out completely, the court will request the appeals court to transfer the books to storage. At this point, the Supreme Court appoints two inspectors to assess the books for quality assurance, which includes reviewing stamps, signatures, dates, and possible gaps. The pages of the book are counted and signed on the first and last page to ensure accuracy. A representative will also do a page-by-page assessment of the book in the presence of inspectors before they are stored.

\section{Officials have reported that the repository contains numerous books with errors}

Officials have indicated that many documents have made their way into storage with numerous errors. According to sources, these errors have generally not been committed intentionally, but are due to the advanced age of inspectors who cannot evaluate documents as required, resulting in minor issues such as dates, stamps, or signatures remaining uncorrected.

\section{3.) Challenges and usurpation within the land transfer procedure}

The registration process is vulnerable at myriad points to unlawful actions.

\section{Insufficient storage and maintenance of land records}

Property Office record books, including the "Heir Book," are maintained in the municipal property directorate, but there is no capacity to store and maintain large amounts of documents.

Land documents and registries have been stored in the Kabul repository since 1911, but many records were destroyed during war. Some documents and registries of neighboring provinces were transferred to repositories in these provinces, but they have now run out of room for additional storage. This has led officials to state that the process of transferring documents between provinces has led to abuses, and that land has been repeatedly transferred without any documentation of ownership.

Officials have admitted that the quality of the paper used for official purposes is very low and it becomes unreadable after a couple years. The Kabul Repository is located underground 
and was not built according to standards, causing it to be vulnerable to moisture from rainwater and humidity. Additionally, there is no air circulation, which causes additional problems for maintaining the records.

Officials at Makhzan have indicated that the digital storage currently in use is insufficient, as the database is managed using Microsoft Access, which is not appropriate for a land registry. Up until 2013, Makhzan has entered numerous records into Microsoft Access, however a new project was launched working with a new software system. It is necessary to completely transfer the data to another database that has more capacity.

\section{4.) Methods of land usurpation}

There are a variety of methods that have been used to usurp land over the years. It has been reported that individuals who have access to the repository (Makhzan) have been bribed or pressured to remove records from the storage. MEC has also learned that, in multiple cases, sheets of the registry are torn from the registration books, destroyed, or in some cases are replaced with forged pages. Another simple practice is the substitution of deeds at the repository, or changing records in the Properties Department, to replace the names of land owners, which reportedly occurs through bribery or threat. Sources indicate that the Primary Court also frequently encounters fake documents and records and there is no advanced equipment that the court can use to identify fraudulent documents. Furthermore, other court officials reported that the authenticity of signatures, seals, and other aspects of documents are often in question.

Forgeries of official affirmation papers lay the groundwork for the usurpation. Individuals prepare an affirmation paper, which shows that the individual has a share of a company. If this company owns land, the individual can therefor, as a shareholder, claim access to the land of latter company and usurp it.

According to court officials, powers of attorney are an easy way to usurp land, because most owners of such land are not present and the usurper can easily present bribed witnesses from local agencies to testify in his favor. Furthermore, forgery of succession certificates is done through secondary units in the provinces and districts, and is possible due to the lack of a detailed and comprehensive census in the country. For example, a usurper can claim that he is the only heir to a piece of land without the proper statistics at the CSO to verify the claim. Land usurpation is also possible by providing fake customary documents, which have reportedly been used on many occasions, particularly in the more rural provinces.

According to court employees, usurpers have also launched numerous false land claims on unregistered lands. One scheme involves two parties who conspire to unlawfully claim the same piece of unsurveyed land without supporting documents. The parties approach the courts claiming ownership, acknowledging that they do not have any kind of documentation or evidence. During the court proceedings, the parties are asked to mediate the ownership issue. Mediation then results in one of them giving up the claim for the benefit of the other, thereby using the courts to validate ownership where none existed previously. 


\section{5.) Transfer of governmental land}

ARAZI functions as the administrator of state properties and processes land transfers to government entities. Land can only be transferred after an analysis of the relevant documents upon request by ARAZI to the Office of the President of Afghanistan.

The Land Management Law outlines the entities involved in the assessment and evaluation of transferable lands including ARAZI, the Cadaster Directorate, MoF, Ministry of Information and Culture and Urban Development, the Environmental Preservation Office, and the municipalities. Representatives from the latter entities form a Land Evaluation and Handover Commission to verify ownerships, determine and grade the quality of the land, type of soil, and the level of land productivity. The MoF determines the value of the transferable land plot and Cadaster officials provide information about whether the plot has been surveyed or not according to Cadaster records (map and list of landowners).

Municipalities provide information whether the land plot is included in the master plan and / or a development plan and provide other strategic information.

The Department of Urban Development develops the initial plan of land required by government agencies and sends it to the Ministry of Urban Development for approval. Implementing the land transfer after the evaluation steps, however, is subject to the approval of the Office of the President. The Offices of the Provincial and District Governors assign qualified delegates to assist with the assessment and valuation of the plot, help with ensuring security of the delegate, facilitate the operation of the delegate through relevant departments, and sign the working papers of the delegate after a decision has been made.

\section{Land transfer procedures are stipulated in the law}

Land transfers between governmental entities are outlined in the Land Transfer and Exchange Procedure. The procedure includes recording in the land transfer books in Kabul and in the principal properties book in the respective province. A Land Assessment and Handover Form identifies the land area, location, boundaries, status, type, value, and other information..

According to the Land Management Law, the petition, including the forms, should be referred to the President's Office for approval. After the approval of the President's Office, the protocol of the land plot will be developed. Once the protocol is signed between the landrecipient agency and ARAZI, it is recorded in the Land Transfer Department and a copy is sent to the recipient agency and land department in the respective province.

\section{The requestor of the land is obliged to develop the land}

The recipient agency is obliged to take over the land from the Agriculture Department of $A R A Z I$ in the respective province, formally assure the proper use of the land, and guarantee that it will be returned if it is used for other purposes. The entity has to initiate its developed plan within six months of the approval of the protocol and preserve the land plot and the environment according to international standards. The agency can only transfer, sell, or lease the land plot to a third party according to the relevant land protocol. 
Land can also be temporarily transferred from the government to non-government entities under similar conditions as described above. Upon completion of the agreed period, the user agency has to return the land to ARAZI.

\section{Land Distribution}

\section{1.) Land distribution by Kabul Municipality}

The duties of municipalities outlined in the Municipality Law include adopting measures for the allotment of land for the construction of homes and businesses and expropriating land in accordance with the Land Expropriation Law. The municipalities also take actions on land distribution, and properties that come under the urban-planning implementation plan. According to the law, there are several types of land distribution, including land distribution based on eligibility, land distribution as compensation for expropriated land, and land distribution for commercial sites.

\section{a.) Distribution based on eligibility}

Land is distributed to those who do not have property and meet other legal requirements related to age and current land ownership. The entitled person must submit their written application to the municipality in order to earn residential land. Kabul Municipality registers the application and refers it to the Department of Properties of municipality for further action. The Department sends it to the Directorate of Land Distribution who provides the applicant with "lack of property form," otherwise known as "circular form". The person is obliged to take it to all 22 districts of the city and assure the Directorate of his lack of property.

\section{Government officials' rights are determined by the assigned commission of Kabul Municipality}

Government officials are entitled to residential land based on their status as employees of the government. Ministries employing eligible recipients will refer applications to Kabul Municipality, which has a commission comprising Kabul's mayor, one of the mayor's deputies, the director of planning and engineering, the general director of properties, and the director of the related district that deals with land issues. The commission verifies the application and determines the land to be allocated. This decision is reported to affected departments for further processing.

The first step is linked to the Directorate of Collecting Revenue of Properties, the second step is the Department of Design and Implementation to inquire about the specifications of land, which is sent to the Department of Properties, the Directorate of Revenue, the Directorate of Land Distribution, and the Map Issuing Directorate. The Revenue Directorate attaches a copy of national identity and two photos of the person and sends it to the Directorate of Land Distribution, which grants the ownership document. After receiving the ownership document, a copy is sent to the Department of Design and Implementation which provides the person with a circular form and refers it to the related district to obtain information on the dimensions and boundaries of the land.

Afterwards, a letter is sent to the Department of Basic Buildings Control of Municipality to provide the person with a form confirming that they do not own any land. Upon completion, 
the form is returned to department with the letter from the Department of Design and Implementation for further processing. Only these three letters, issued from the Department of Basic Buildings Control of Municipality, the related district, and district police office allow the applicant to start construction work.

\section{The applicant shall complete $40 \%$ of construction work within three years to receive the legal deed}

According to the Regulation for Distribution and Selling Residential Lands, offices of municipality and other related organizations are compelled to transfer the land to the entitled person within 3-to-6 months and give him permission to build on his land. Once the person completes $40 \%$ of the construction work, he is entitled to a legal deed. The deed is issued after an application is made to the municipality, which certifies the documents and forwards the file to the relevant court for the issuance of a legal deed.

\section{b.) Distribution as compensation for expropriated land}

Land of equal value may be distributed as compensation for expropriated land. The expropriation of land is initiated when the Department of Design and Implementation of Kabul Municipality marks the area and refers it to the Department of Expropriation of Municipality. The Department of Expropriation inquiries into the amount of lands coming under the plan of expansion, registers the relevant property, and determines the price of the land. The "price fixing" form is sent to the Directorate of Expropriated Land Districts who refers it via the Office of Kabul province to the appeals court of Kabul province.

Three months prior to land expropriation its owner, user, or their representatives is informed about the expropriation and price by the municipality. In a hearing, the appeals court confirms the individual's acknowledgment to transfer land to the government and prepares the expropriated deed. The deed is sent by letter to the Kabul Municipality Department of Expropriation for further action. In this process, the local relevant authorities are informed of the expropriation so that they can register it in their property registration book as government land.

\section{The landowner is obliged to provide all legal documents in order to be compensated}

After the process of expropriation is finalized, the paperwork is transferred to the Department of Properties and sent to the Files Investigation Committee to restore the property owner's rights. The Files Investigation Committee assesses the characteristic of land documents or demolished properties, as well as the type of documents for ownership (legal or conventional deed). If there is a conventional deed, the individual is entitled to a residential land for compensation, and if there is legal deed the equivalent value of the land is paid.

In exchange for the price of expropriated land, the landowner can be provided with an equivalent piece of land. In these cases, the Department of Design and Implementation of Municipality specifies the dimension of the land to be distributed to an individual and submits it to the related district for specifying the dimensions of the land. Upon receiving the related district's response, the Department of Properties prepares the new ownership document. If the new land is better than the expropriate one, the landowner pays the difference. 


\section{c.) Distribution of land for commercial sites}

If an individual, an organization, or a company wants to obtain land for commercial purposes, a request has to be submitted through a special form to the Kabul Municipality. The Municipality compares the form with the Urban Plan. In case of agreement, the Municipality issues a license for the owner of the land.

\section{d.) Methods of land usurpation within Kabul Municipality}

Land usurpation has become a major problem for Kabul Municipality, often occurring by force. Research findings indicate that hundreds of land plots were grabbed by force, including areas allocated to schools, clinics, mosques, and other facilities by Kabul Municipality. According to research findings, land usurpers have grabbed land before 2012 when the municipality and police forces were not able to intervene due to a lack of coordination.

Officials of Kabul Municipality link land usurpation in Kabul to the weakness and unwillingness of law enforcement entities to protect governmental lands and properties. They believe in certain cases police officials themselves have been involved in land usurpation by accepting bribes. It has been reported that people without shelter took land in non-planned areas.

\section{Corruption by government officials}

There are reports that the required signatures and documents from various departments of Kabul Municipality are being forged and falsified, including the falsification of valuation cards by expropriation teams who distribute additional land-valuation cards to receive property in return.

Interviewees have reported that the illegal collection of money in various ways during the land-distribution processes is wide spread. One example is supported by reports of brokers paying bribes to officials who process circular forms to verify a lack of land ownership on behalf of applicants, when in fact the applicant owns land. Another example is the collection of bribes during the valuation process of the land to be expropriated, with higher valuations being given for those who pay bribes. Cases have been reported, where municipal staff has apparently threatened to exchange deeds during the distribution process for less worthy plots, if a person did not pay a bribe. Interviewees stated that without knowing someone personally in the municipality, it is impossible to get your land plot even if you are eligible.

It has come to MEC's attention that in Kabul Municipality commercial sites are being sold to specific persons outside of the process. When lands are identified to be commercial land, plots are being sold prior to the announcement of the designation.

\section{High officials have illegally ordered the distribution of land}

Multiple sources have indicated that influential people have received land on the direct order of high ranking officials who ordered that land to be provided to individuals who were not legally entitled to receive it. Interviewees have indicated that people are demanding their land plots and the municipality has no land to distribute. The evaluation of the distribution process in Kabul Municipality shows that this institution has handed over 42,000 deeds 
without distributing the lands to them. The Municipality has been able to distribute only land for 4,000 deeds. Satisfying influential people, lack of insufficient tracking of available land, and the existence of widespread corruption appear to be the main causes of this problem.

\section{2.) Land distribution by MoRR}

Based on a 2005 decree, MORR has the mandate to distribute unutilized governmental lands to returnees and displaced people who are in desperate need of shelter. According to MoRR, they have distributed 68,426 pieces of lands in 62 places across the country and plan to distribute more in the future. Eligibility is based on citizenship, proof of returning from displacement, and the lack of land in Afghanistan. Currently, the process of land distribution to returnees and internal displaced people includes 63 steps.

Furthermore, PD 45 obliged MoRR to develop a concrete plan for constructing townships, providing education for refugees, and reporting on the equal distribution of refugee's township in 34 provinces. In response, MoRR reported that a delegation was sent to 24 provinces where refugee townships are located to assess the issue. On the basis of this report, MoRR planned 62 townships (on 170,160 Jeribs of land) in 29 provinces, from which 36 townships (on 90,172 Jeribs land) were opened in 22 provinces.

Data indicate that, so far, 406,883 petitions demanding land are registered in the Department of Refugee and Returnees in Kabul and the provinces from which 114,244 families were recognized as eligible by the designated commission. As many as 72,011 families paid land charges to the government, and 68,426 families received lands, with 30,414 building their houses and 22,310 residing in refugee townships. Of these, 39,846 families have also received temporary ownership documents.

Officials from MoRR have reported a lack of cooperation from relevant government organizations for providing basic services in refugee townships and insufficient cooperation from security forces as challenges to resettlement.

\section{a.) Methods of usurpation in the MoRR townships}

MoRR has not been immune from land usurpation in its distribution process. The ministry has acknowledged that its lands have been usurped in some provinces, such as Lagman, Rabat (Gardiz), the Namgan plain of Kapisa, Khost, Kabul, and the Khaja Alwan Plain of Baglan. It is not known how many pieces of lands have been usurped, but sources from within the ministry say that 2,121 pieces of land have been restored which were previously distributed illegally in Balkh, Baglan, and Khost.

Abuse of power is the most common method of land usurpation, as findings indicate that refugee townships are often usurped by the governmental and powerful individuals. Findings indicate that the issuance of exceptional orders by high-ranking government authorities also gives rise to the distribution of land to ineligible people. Reportedly, highranking authorities refer exceptional orders to MoRR to distribute land in contradiction with the Decree No 104. It has been reported that such orders are given verbally by high ranking officials to MoRR. MoRR highlighted the issue of distributing land on the basis of invalid documents and exceptional orders in its report concerning the implementation of the PD 45. 


\section{3.) Endowed Lands of the Ministry of Haj and Religious Affairs}

The Endowment Department of the MOHRA is responsible for regulating and safeguarding lands endowed for public or charitable purposes. This includes registration, control and evaluation of endowed areas, reconstruction and maintenance of shrines, identifying and obtaining new endowed properties, recovering usurped endowments, conflict resolution of endowed lands files through the Government Cases Department, and building shops and markets in endowed areas to raise revenue.

According to officials, the ministry has more than 49,743 Jeribs of land under its control, with Herat, Balkh, Kunduz, Badakhshan, Kandahar, Takhar and Badakhshan having the most endowed lands and shrines. However, there is a concern with the accuracy of this information, as some provinces do not submit proper reports. For example, Kandahar province reports that the size of endowed lands equals the amount of usurped endowed land, meaning that all endowed land appear to be usurped, which appears to be doubtful. Other provinces such as Panjshir, however, appear not to have any endowed land which seems unlikely.

There is no written procedure for regulating endowed lands and the Department of Endowment utilizes civil law and procedure that is not appropriate, but the Department is working on draft legislation to clarify the procedures. Currently, an individual who wants to endow land must apply to the ministry with details about the size of the land, certifying that the land is not under dispute, and setting out the purpose for which the land is endowed. The ministry attaches a copy of the request to a letter and sends to the concerned departments like Department of Municipal Property, Courts and Property Directorate of MoF.

The ministry has the responsibility to enforce the terms of the endowment and care for the lands and materials. Unfortunately, a number of opportunistic and powerful individuals have usurped certain endowed lands with a number coming into the possession of government agencies. The roots of this problem lies in the fact that that few documents were arranged for endowed lands previously, and there was a lack of awareness of the legislation and registration. Officials of the Ministry stated that there are many endowed lands that have not gone through the procedure of registration in the government registration offices.

According to a report from the Endowment Directorate, 32,838 Jeribs of endowed land have been usurped. Of this, it is estimated that 10,200 Jeribs have been usurped by ministries and government agencies and 10,057 by municipalities, with the Education Department and Department of Refugees and Returnees are the highest ranking usurpers.

Most land that has been endowed is cemetery land, which also forms the highest number of endowed land being usurped. Cemeteries are particularly vulnerable as they are not registered, and only the area and its location are recorded. Research findings indicate that a number of cemeteries have been usurped by some state institutions and people with high buildings being constructed. In one case, this was verified by locals digging a water stream who were confronted with human bones.

Officials of the Endowment Department stated that through a lot of effort in the restitution of endowed property certain successes have been achieved. As a result of efforts made by the Department, over 1,121 Jeribs of land were restored. 
Lack of cooperation with relevant government agencies is one of the major challenges facing the ministry. Most people do not have knowledge of endowed lands to support and cooperate with the Endowment Directorate, particularly public servants. However, officials say that governmental agencies not only withhold support, but actually sabotage the process. Particularly municipalities distribute endowed land without obtaining the approval of the Endowment Directorate. Municipalities have reportedly usurped land without any plausible acquisition document. Provincial reporting is also often incomplete, and the size, position, or even usurper's name is not included.

Officials also identified some locals as being responsible for usurpation by falsely claiming that land was endowed to them. In some cases, individuals and residents avoid testifying against powerful people.

The Department of Government Cases is responsible for the defense of public properties, but has not been very successful in this regard. Its inability appears to relate to the lack of defensive tools and a shortage of prosecutors resulting in decreased efforts to obtain evidence.

Survey and registration of endowed properties could reduce the usurpation of endowed land and facilitate restitution. It has been more than three years since the Endowment Directorate presented a proposal to MoF, requesting the assistance of the Cadaster Department to allocate a budget to survey endowed properties, however no such budget has been allocated.

\section{Formal Dispute Resolution}

\section{1.) Addressing land usurpation cases through the Department of Legal Rights (Huquq)}

Land usurpation in Afghanistan is defined by the Civil Code as a civil action and the Department of Legal Rights is the first point of contact in resolving disputes. Petitioners who directly present petitions to the court will be referred to the Legal Department. The Department of the Huquq operates within the framework of the MoJ countrywide and is specifically responsible for dealing with the rights of legal and real persons, defending property rights, and taking measures to impose decisions of the court on civil-rights disputes.

According to officials of the Legal Rights Department, property-related issues often create complex problems due to the lack of certificates, the involvement of many stakeholders, and powerful individuals trying to influence the process. Sources have indicated that influential individuals often put pressure on plaintiffs to force them to withdraw their complaints.

\section{2.) Dispute resolution procedures initiated by the Huquq Department}

Cases referred to the Huquq Department follow four steps: the administrativeproc ess, review and acquiring rights, addressing the case, and enforcement of the judgment.

\section{a.) Administrative steps}

The administrative step starts with a petition supported by a claim form with all case-related data. When the petition is received by the Legal Rights Department, it is registered by the 
clerk in the petitions registration book. At this stage, the petitioner has a number of obligations, including attaching all acceptable rights-related documents.

The ANP / MOI are legally bound to present the defendant to the Legal Department. In practice, the petitioner often has to take a subpoena to the police department in the field to ask for cooperation of the police. Once the defendant is contacted, the Huquq requests him to provide guarantors. Once the defendant is questioned by the Huquq Department, a case file is created including all facts presented, as well as the relevant evidence.

\section{b.) Investigation and acquisition of rights}

After completion of the administrative process, the investigative stage begins. The department has the right to summon relevant persons for questioning. A professional officer reviews the petitions, communicates with the defendant, and presents his report to the Professional Implementation Section of the Legal Rights Department.

According to the law, the only valid documents to base a claim on are those issued and prepared by competent courts in a definitive and final manner, documents that have been prepared in embassies and political agencies of Afghanistan and have been acknowledged by the Ministry of Foreign Affairs, final decisions from foreign courts in cases between foreigners and Afghans based on the rules of international private rights and confirmed by the Ministry of Foreign Affairs, and documents that have legal and Sharia credibility.

Where the Legal Rights Department suspects that any document is counterfeit, it refers it to the relevant court for verification who may further refer the document to relevant authorities. However, there are questions as to whether the relevant district courts have the capacity to verify false documents and documents are often sent to Kabul courts in practice, leading to significant delays.

If the evidence substantiates the claim, the Legal Rights Department is obliged to hand over the relevant property to the lawful claimant within ten days. If that is not possible, the parties are invited to negotiate, and the Department acts as a mediator to solve the problem. The report on the negotiations is then sent to the Legal Rights Directorate.

If the claim does not require any investigation, if the petitioner presents invalid or fake documents, or if the defendant renounces the claim of the petitioner, and mediation was not successful, the case is sent together with the petitions to the competent court. If the petitioner does not follow up his petition within one month with the Legal Rights Department, the petition will be stored in the capital according to the instructions of the Directorate of the Huquq and in the provinces based on the proposal of the Legal Rights Section and instructions of the provincial governor.

\section{Conflict resolution on complex cases involves the Committee on Estates}

An expert committee within the Huquq Department deals with complex land cases that cannot be resolved in the provinces. The Committee on Estates studies and investigates legal rights in regard to estates that are received from the provinces for advice. Members of the Committee are entitled to enforce Sharia documents and final resolutions of the courts countrywide. Cases that are not resolved at this stage are referred to the courts. 


\section{c.) Challenges to the resolution of disputes within the Huquq}

\section{The Legal Rights Department faces several challenges that affect their ability to uphold the dispute-resolution process}

The Legal Rights Department plays an important role in reducing and resolving the number of civil cases, but also faces challenges to fulfilling its responsibilities. For example, the Legal Rights Department of Kabul province is situated at the headquarters of the Kabul Provincial Governor's compound and works in small, overcrowded, and dark rooms unsuitable for discussing cases. In the provinces, officials also often face threats from powerful individuals who do not have any respect for the law and disregard official decisions. Members of the enforcement delegations face severe reactions, including violence.

The awareness of codified law is very low across Afghanistan, and individuals are unaware of their rights. Interviewees from the Legal Rights Department consider the low level of awareness of laws among the population as a significant challenge to the performance of its duties. The Department is also faced with the physical absence of the defendant and guarantor in court proceedings, often in an attempt to avoid or delay the case. In such cases, the Legal Rights Department will be forced to use compulsory enforcement, which adds complexity, difficulty, and delay.

The Legal Rights Department should be the first agency to receive cases or petitions, in practice, however, cases are often given first to other agencies, such as the police (MOI) or AGO. These agencies review and process the files before sending them to the Legal Rights Department, thereby breaching Afghan law. In addition, this decreases the chances of cases being resolved in the conciliation and negotiation stages. According the officials at the Legal Rights Department, the Presidential Decree 45 has improved this situation, but various reports suggest that investigations are still being carried out by other agencies, particularly the AGO. Finally, there are reported instances where officers of the Legal Department have delayed the implementation process due to personal relationships with the defendants by receiving incentives, such as bribes.

\section{d.) Procedures at the courts}

\section{Primary Courts are the court of first instance for claims}

The claimant is obliged to submit his dispute to the court with specific and detailed information about the land/property in question. At least the names of three neighbors and their fathers and grandfathers should be provided. There should be information about the method of usurpation of the property and its date. If the claimant cannot submit his claims to the court within 15 days, the court will issue a judgment to drop the case and reject the petition.

\section{The acknowledgement of the defendant's ownership proves the claim of ownership}

The claimant reads the case in the presence of the defendant at a preliminary court hearing. Afterwards, the claimant is asked to call at least two witnesses and a hearing is scheduled to hear the witnesses if the claimant is able to do so. When witness testimony is acknowledged by the court, a claim statement along with the inquiry letter is given to the defendant to 
prepare his defense statement, which must be submitted to the court within 15 days, after which the parties are notified of the trial date.

If the claim is based on customary documents, the court needs to perform further investigations. Research is performed to check the names of the property owners in the Property Department, Administrative District Office, or Tax Department. Documents containing fingerprints of the claimant for the sale of the property will be verified through the Criminal Techniques Department of $\mathrm{MOI}$ for verification by cross-referencing with the original legal deed in the legal-documents archive.

The plaintiff must follow the case proceedings on a continuous basis or he will lose the right to pursue the claim. If the plaintiff does not follow-up with the court on the case within 30 days, a decision will be made regarding the abandonment of the lawsuit.

\section{Appealing cases from the Primary Court}

If the claimant or defendant is not satisfied with the decision of the Primary Court he can file a notice to appeal within 30 days, and all documents must be filed within 20 days. But the Court will not hear cases where the value of the property claimed is not more than 100,000 Afghanis. The appeal has to include new evidence of the claim or provide reasons for challenging the judgment. At this stage, third parties may also become an appellant with supporting documents. The opposing party is given time to present his case after receiving a copy of the case. After hearings and completion of the case assessment, the judicial team makes a decision amending, disregarding, approving, or abolishing the decision of the lower court.

\section{Addressing cases in the Supreme Court}

Appeals to the Supreme Court are exceptional, and not a right. If the Supreme Court finds that the decision by the lower court is against the law or there are errors in the interpretation or implementation of the law, such decisions become invalidated and are referred to the lower court for redetermination. However, if the verdict is correct and constitutional then it will be validated.

\section{Revisions are bound to strict limitations}

The stage of revision may occur where a final decision of the Primary Court is proven to be incorrect. Objections may be submitted to the High Council of the Supreme Court within three months of a final decision based on evidence of false testimony, false evidence, fraud in evidentiary documents, false translation, or supporting documents that did not exist. The judicial meetings of the High Council of the Supreme Court consider and accept requests and issue rulings to nullify the final orders before the issue is referred to the lower court, where appropriate.

\section{e.) Adoption and enforcement of court orders}

Final orders of the courts are referred to the Huquq for implementation and enforcement. Huqaq assigns a delegation to go to the field and enforce the ruling, including removal of a usurper, at the land owner's request and at permission of the court. Monitoring the 
implementation takes place through the Department on Monitoring the Enforcement of Final Judgments of the Courts in the Supreme Court.

The enforcement delegation includes officers of the Legal Rights Department, municipal, police and a local representative (parish representative, local elder, neighbor, etc.). The goal is to have witnesses from the community to ensure transparency of the delegation's actions. Depending on the nature of the case, representatives of the AGO join the delegation as well as human rights organizations.

If the delegation cannot implement the order for any reasons, including interference from powerful individuals or construction completed on the property, the delegation informs the court that it is "difficult to enforce and implement." The court will then take action to remove the obstacles to implement the ruling and may order the Legal Department to take measures to solve the problem. The delegation returns to the field and may even use force to implement the order. The Supreme Court may also make an order for enforcement upon petition of the successful claimant.

According to the Penal Code resistance towards executive bodies enforcing court orders is punishable with a short imprisonment. If there is a problem in the department responsible for implementing, the department contacts the MOJ or introduces the responsible employee to the administrative corruption section of the AGO.

\section{f.) Challenges within the formal judiciary}

The courts face various problems related to litigants who are unaware of court proceedings or present allegations that appear to be irrelevant or false. There are many documents and deeds in which dimensions of property have not been mentioned or are ambiguous. There also appears to be a lack of access to information regarding the land/property in dispute.

It sometimes takes weeks for the information to be received by the court, and some entities do not respond. This issue is compounded by the practice of destroying property documents from the archive. Issues also arise where the courts decide inheritance cases contrary to the dominant cultural practice of giving the property to the elder sons, which dispossesses other family members, especially women. There are a large number of family cases where inherited land is usurped by the members of family themselves

Problems often occur when the defendant has had possession over the property for a long time and presents "false" ownership documents. According to judges, large numbers of cases relate to people who do not have any type of property rights to claim, but want to put pressure individuals to obtain some money from them, or assuming that they might be called to compromise with each other.

According to court officials, the lack of safety and security has caused problems in carrying out their duties. Some judges reported that they have been chased, threatened, warned and beaten, including the court employees' family members. According to sources, threats to kill court employees are not uncommon, if judicial staff refuse to process and execute forged records (e.g. forgery of succession certificates). If the defendant is a powerful person, the ANP is often not able to summon him to court. Interviewees have reported that when they 
task the ANP to summon one of the parties involved, the request is being rejected or simply ignored.

It has also been observed that the AGO has interfered in cases thereby creating problems for the courts. Some cases may have criminal and civil aspects and the AGO is expected to resolve the criminal aspect and refer the civil aspects to the court. However, there are reports that the AGO uses these criminal aspects - sometimes of a very trifling nature - to extract payments from claimants.

Finally, the courts face several challenges related to case management and the recording of judgments. Cases have occurred where previous court rulings have been ignored and the same case was raised again in order to receive a different judgment. Many of the same cases are reportedly being run in various courts simultaneously therefore risking contradictory outcomes.

\section{3.) Governmental Land Cases}

The Land Management Law defines governmental lands as all agricultural and nonagricultural land registered in the governmental land registration book, lands not proved as properties of individuals, lands registered as governmental properties before Aug 6, 1975 and lands in the possession of government for over 15 years before Dec 27, 1979.

There are no significant differences in processing cases where the government is party to a suit versus where the litigants are private individuals, except that cases involving government will be pursued by the Department of Government Cases.

The Department of the Government Cases was established within the MoJ to represent the government in civil cases and the Government Cases Law, last amended in 2013, stipulates the working procedures for the department. When government entities become aware that their lands have been usurped, they make a request for investigation to the Department of Government Cases, together with all documents and evidence. The Department is compelled to call for related documents from real or legal persons as soon as it receives a request. If a party to the suit fails to present the related documentation within the allocated time, the department issues an order of property restitution to the relevant government entity, which can be rejected by a party. If the party fails to submit documents to the court within 15 days, however, the court will consider the resolution by the government cases department and come to a decision.

Legal disputes between government entities are generally resolved through discussions and reconciliation. If the dispute is not resolved, the Department of Government Cases is called upon to solve the issue, without use of the courts. A professional member of the Department considers the evidence and issues an order with both parties' agreement and signature.

\section{a.) Court procedures regarding governmental land}

The Civil Procedure Code stipulates that the Department of Government Cases is the only entity competent to represent the government in civil cases and is the only entity that submits files related to the government usurped lands to the public rights courts. The public rights court firstly considers its authorities and subject of the claim and then listens to the 
statements and defense of the parties. If the issue needs investigation, the court issues an order to process the case, otherwise it dismisses the case.

Government representatives have no right of waiver, and the government is compelled to pursue the case through the entirety of the judicial system. The Department of Government Cases is charged with warding off the emergence of any occupier to safeguard public assets until the issuance of court's final judgment, with the assistance of the police and other government officials.

In cases where the Department of Government Cases becomes the losing party, it should pursue the case up to the Supreme Court. If the court's final judgment is issued at the disadvantage of government and later new evidence suggests otherwise, MoJ is compelled to ask the Supreme Court to review the matter.

\section{Expropriation in cases until final decision by the court}

The government expropriates land when the law recognizes the land as the government's possession unless an individual can prove his ownership. The clarification of documents is an individual's duty and, if he has no proven documentation of the land he possesses, then the land is regarded as government property. The land subject to a claim between the government and an individual should remain in the possession of government until the case is resolved. In cases of a party's resistance, the Department of Government Cases should request help from the police.

\section{b.) Challenges related to the Department of Government Cases}

Proportionately, very few cases of land usurpation of government lands have been sent to the courts, with less than 200 being referred in 2013; this, despite a new Law of Government Cases, which enabled the Department of Government Cases to investigate cases more efficiently. According to the law, the return of property should take place in 20 days, while it normally occurs in three-to-four months. The new law creates administrative penalties for institutions for non-cooperating agencies.

According to a member of staff of the Department, employees are often threatened by usurpers by phone or receive direct death threats and interviewees complain that security forces have paid insufficient attention to protecting them. The Department also faces severe logistical issues, as they lack vehicles for official activities and their office is reportedly not yet connected to the internet.

\section{Informal Dispute Resolution}

\section{1.) Informal dispute resolution in Afghanistan}

Despite the existence of official structures to manage land affairs, many aspects, such as transactions and tenure security, are regulated by religious rules and solved through customary processes. A survey regarding the role of the informal justice system in resolving disputes, including land and property disputes, indicates that a majority of disputes are resolved outside of the formal system, with estimates ranging from $58-80 \%$ of cases.

In Afghanistan, the informal dispute resolution system generally refers to Shuras / Jirgas that are used to address various issues, particularly in areas where the government has a limited 
presence. This is a centuries-old system for resolving disputes and is deeply entrenched in the Afghan culture with many Afghans turning to traditional justice mechanisms, even in areas where formal justice institutions are active. The poorly functioning formal justice system, the existence of illiterate and untrained judges and legal professionals, widespread corruption, expensive and time-consuming procedures, and a focus on punishment more than on reconciliation, are among the reasons leading people toward Informal justice systems. The informal justice system appears to have many comparative benefits, including being less expensive, providing resolutions that benefit the whole community, and enhanced transparency.

\section{Customary rules have not been fully integrated into the formal land system}

Although the Jirga system is based on consensus of participants, the system may not always correspond to national law, Sharia law, and international human-rights standards. In 2010, an effort was made to provide legal recognition of the informal justice system with the MOJ drafting the Law on Dispute Resolution Shura and Jirga in coordination with MoWA, AGO, USIP, the British and US embassies, and other entities. This law determines the duties and authorities of Shuras and Jirgas and the validity of their decisions in the justice institutions. The law limits the authority of Shuras to civil cases, and prohibits it from handling criminal matters, as well as cases involving government and public property. However, the law was removed from the MOJ list of priorities by presidential order, apparently due to objections that it infringes on the jurisdiction of the courts.

\section{Various entities are involved in administering informal dispute resolution}

Many donors appear to be interested in developing IDR mechanisms in Afghanistan, as various Shuras are formed to address disputes in communities. There have been many institutions in Afghanistan addressing land disputes through IDR, such as USIP, TLO, and NRC. In 2013 USIP, with the support of ARAZI, started pilot projects in Kunduz and Khost on Land Conflict Resolution through its implementing partners (TLO and PTRO) by working with Shuras in coordination with ARAZI sub-offices. The pilot project may help to establish permanent Shuras and to identify the most effective procedures for resolving land cases. However, given that land usurpation cases are usually complex, they are often referred to courts by most organizations dealing with dispute resolution.

\section{2.) Procedures within Shuras and Jirgas}

There are permanent and ad hoc Shuras, with district and village level Shuras being examples of permanent Shuras whose members are selected through informal election. There are often specific Shuras to deal with particular issues in the community such as education, Ulema, youth, and women. Most disputes resolved through informal mechanisms are assisted by permanent Shuras where both parties agree, otherwise an ad hoc Shura will be formed composed of trusted members of both parties, such as Masjid imams, relatives, or community elders. The conflicting parties have the authority to accept or reject any members of the Shura as mediators.

Communities have their own local rules and principles, which provide for different interpretation of disputes, but Shuras will generally start by interviewing the parties, relatives, and neighbors, and by requesting supporting documents. Shuras often negotiate with both 
parties separately to explain the reasons of a potential decision and to assess their reaction before a final decision is announced. In some complex cases, the Shura takes guarantees from both parties before announcing the final decision. Both parties have to accept the decision; otherwise they will lose the money or whatever they may have given as a guarantee.

\section{3.) Challenges of the Informal Dispute Resolution Process}

Although Shuras have many benefits, they are also not immune to some of the concerns prevalent in the formal justice sector, including the potential for influence and interference from powerful individuals. It has been reported that decisions of Shuras are influenced by powerful figures in the community, including by use of threats. Shura decisions can also be difficult to implement when they are not accepted by one party, as they lack legal recognition.

Although some NGOs have provided legal awareness training to hundreds of Shura members, there many Shuras that enforce decisions on civil and criminal disputes without having basic constitutional and legal knowledge. In addition, some Shuras prosecute and punish criminals for serious crimes, which is actually the exclusive authority of the state.

It has been reported that, especially in family and land disputes, Shura decisions often benefit men. Some studies clarify that the abuse of women's rights is not a common concern in all Shuras, but other case studies show that special attention and respect is paid to women.

\section{Land Usurpation in the Provinces}

\section{1.) Balkh Province}

Balkh province has a high number of land usurpation cases relative to other provinces in Afghanistan. According to reports from ARAZI approximately 194,756 Jeribs of government land has been usurped in the province, although authorities in Balkh and ARAZI connect the problem to the 1970's and 1980's while political parties were in power. ARAZI reports that little usurpation has taken place in Balkh outside of those supported by documents from those decades. The Supreme Court has issued a decision that has invalidated such documents.

It appears implausible to tie all land usurpation to the 1970's and 1980's as there are vulnerabilities in the land system. For example, the Cadaster Department was providing statistics and specifications of unregistered government land to usurpers, which they used to create fake documents. It has also been reported that some employees started burning the Land Registration Department to pave the ground for land usurpation.

Other interviewees assert that the courts were involved in the process of land usurpation and creation of forged and fraudulent deeds with some calling the Balkh Court Office "a center of corruption and forgery". It is reported that a number of towns have been constructed after being usurped based on forged deeds made by the court. Staff and judges reported that they would be removed from their positions or killed if they did not help land grabbers in providing forged deeds. 
Land usurpation in Balkh province has also been conducted by government institutions, with the Provincial land department complaining that the military headquarters of MOD, NDS and Municipality of the province have acquired government lands improperly.

It appears that the municipality is also involved in forgery and corruption cases, as during the land distribution program they distributed one piece of land to two different people at the same time. According to land department officials, Balkh municipality officials also embezzle the incomes received from the land distribution process requiring serious investigation.

\section{Most cases of land usurpation in the private sector, whether in Justice (Huquq) department or in a court office remained unsolved}

Provincial Justice (Hukook) Department officials claim that land usurpation has also happened in the private sector, but at a lower rate than government lands. Property has been usurped by preparing forged powers of attorney, inheritance letters, customary documents, and deeds. For example a person or group of people may have property documents from the era of Dr. Najeeb's government from 1987-1992 and change the figures. According to Justice (Huquq) Department officials, it has been seen many times that land usurpers have changed 100 Jeribs into 1,000 Jeribs.

Interviewees often blame the Cadaster office, property office, and courts as the root of the usurpation of private land. They accuse them of forgery as signed and stamped documents are not possible without involvement of the administrations. Employees of the court repeatedly provided legal deeds for land usurpers, however, when they were informed about internal investigation, they immediately invalidated the false attached sentence to the deed. According to officials from the Legal Department, the court has also ruled in favor of people accused of land usurpation, indicating a high level of violation and corruption in these institutions.

Usurpation occurs through property-dealing offices as well. Property has been sold surreptitiously without the owner's approval after owners recorded their land or property for rent or mortgage in the property-dealing office. The usurpation of the lands by propertydealing offices mostly takes place when property owners live outside Afghanistan. In addition, the offices of property dealers are using this opportunity to forge customary documents.

\section{2.) Herat Province}

Herat is another province with a relatively high rate of land usurpation. According to recent reports from ARAZI, 70,698 Jeribs of government land has been usurped, with the numbers increasing over the last decade. Many owners are in possession of temporary customary documents that do not include any specific measures for the land, but rather refer the outlines of the land to landmarks.

Forgery of documents, land distribution orders, and usurpation by force are the main methods used to grab public and private lands in Herat. Herat municipality faces a lack of lands and, according to officials, institutions have received decrees of land for 25,000 houses, of which 15,000 have been distributed with no land available for the remaining. Herat municipality officials reported that land titles were given to those applicants, despite 
not having enough land to distribute to silence protests. About 3,000 people have received documents without land, and 7,000 people have no land or documents.

The Land Department has a limited organizational structure and employees have often been threatened by land usurpers. The ANP and provincial AGO are not properly cooperating to combat land usurpation. Judges and court employees have reportedly been killed when disputes between government entities and land usurpers have been decided in favor of the government.

Powerful people and high ranking officials are supporting land usurpers so that the government is unable to fight against them. Cases have been found in courts that indicate that court employees are favoring one party in exchange for bribes, or sometimes through pressure from powerful individuals.

\section{3.) Nangarhar Province}

About 30,584 Jeribs of government land have been usurped by 740 usurpers in Nangarhar province. Officials in Nangarhar say that, during the Communist Regime, land was mostly distributed to people who shared the same ideology as the government. In Nangarhar, the forgery methods are similar to the ones mentioned in other provinces.

There are many examples where people do not return government land, as specified in their lease contract. People who are given lands through the leasing process later claim that they have owned the lands for many years. This is facilitated by poor record keeping. Contrary to the terms of contract, tenants construct buildings on the leased lands and benefit from the Land Leasing Procedure, which stipulates that buildings constructed that cost more than the land cannot be retaken. Instead, a small payment is made for the land.

Another concern is the presence of powerful and influential people who have usurped government lands. Officials stated, that "while usurpers were grabbing lands behind the governor's office, we could clearly hear their voices, but the governor couldn't react against them".

Finally, in Nangarhar people who register their land in Property Dealing Office for sale and or for rent have their property sold without their approval, causing many cases to come to the courts, where the AGO reportedly regularly interferes in civil cases.

\section{Land belonging to the Canal Directorate has been usurped in a variety of ways}

The majority of usurped government land in Nangarhar belongs to the Canal Directorate. AISA has started distribution of canal lands for the purpose of building an industrial town without notice or clearance from the Canal Directorate. The number of land plots distributed by AISA is higher than allowed by the decree. A similar example of this is the Police Town (Sharak Police) where, instead of 1,800 land plots, 9,000 land plots were distributed based on a decree that allocated the lands, but had not approved the distribution from ARAZI. There are also reports that staff of the Canal Directorate were misusing their authority to usurp a portion of Canal Directorate's land, resulting in their termination. 
The Canal Directorate faces many challenges to addressing the usurpation of their land, including a small Tashkil for their police directorate, and the unwillingness of police, courts, and attorneys to coordinate and cooperate.

\section{4.) Kapisa Province}

Kapisa is one of the smallest provinces of Afghanistan and few people there own land. Despite it being mountainous and unsuitable for agriculture, land usurpation exists in the province due to its proximity to Kabul. According to ARAZI, 1,464 Jeribs of land have been usurped by 1,473 usurpers, but few cases exist where more than one acre of land has been usurped. In fact, the majority of land has been usurped by poor and homeless people with government land mostly taken illegally by individuals and different tribes. Over time they extended their lands and were farming the surrounding lands for their personal use.

Kapisa, as other provinces, also has serious problems with government institutions and offices, with 36 Jeribs of government land illegally usurped by 14 government institutions. Interviewees have reported that some of the government land usurpers have used government decrees to sell hundreds of Jeribs of land.

Government measures in returning the usurped lands appear to be weak. Officials of the majority of judicial offices, especially the local ARAZI office, Department of Government Cases, and Justice (Huquq) Department complained about the ineffectiveness of the police and other authorities.

\section{5.) Challenges of land usurpation throughout Afghanistan}

There is significant variation in land usurpation in various provinces. Most land usurpation has occurred in Balkh, Helmand, Nemroz, Qandahar, and Herat province, with Bamyan and Laghman seeing relatively lower levels. One of the main factors behind the high rate of land usurpation is the presence of warlords and powerful locals who are very strong and government institutions cannot protect governmental and private lands against them.

Another reason behind the high rate of land usurpation in Balkh, Nimroz, Helmand, Nangarhar, Kandahar, Herat, and Kabul is their important commercial and political locations. The thriving real estate markets in these provinces also contributes. Although the cost of land fluctuates daily, it is not comparable to the costs of land in other provinces. Finally, fertile lands in some of these provinces are also attractive to usurpers who wish to cultivate opium.

\section{Efforts to Tackle Land Usurpation}

\section{1.) Legislative Initiatives}

\section{Land-management law}

The Afghan government, with the assistance from the international community, adopted a new land policy in 2007 to ensure access to land for every Afghan and to establish a sufficient system of land administration. Based on this policy, the Law on Management of Land Affairs was adopted in 2008 with the aim of creating a credible system for land affairs, 
including the registration of land in property offices and addressing the problems arising from the implementation of previous regimes. The Law on Management of Land Affairs stipulates commissions at the central and provincial levels to manage land affairs, but they have not been effective to date and land administration still remains over-centralized. Furthermore, land administration is still overly dependent upon presidential dictates and the measures introduced against land usurpation are weak.

Instead of improving the situation, they have led to more complications regarding the lack of judgments based on documents and the adverse possession of land under possession for more than 35 years. Some people have also benefited through the bribery of community members and presenting them as witnesses in court to obtain legal land documents, with thousands of Jeribs of land being usurped via this maneuver.

Considering the problems, the Land Management Law of 2008 has been amended by ARAZI, but the proposed amendments are still with MOJ and have not been finalized. In 2011, the proposed draft law was presented in public consultation sessions in Kabul and across the country. At the end of this year-long process, a public meeting with the participation of stakeholders was held, in which the proposed land management law draft was finalized. The draft law attempts to prevent land usurpation, handle disputes, and increase government revenues from leasing properties.

Additionally, a draft of the Law on Usurpation and Illegal Occupation of Private and State Land was adopted by the Wolesi Jirga in 2013 and presented to the President for approval. The draft law criminalizes land usurpation and stipulates imprisonment for offenders. However, it was rejected and sent back to parliament for amendment, but has not progressed further.

\section{Presidential Decrees and Council of Ministers decisions}

PD 104 was issued in 2005 to address land issues related to returnees; PD 45 was issued in 2012 to deal, in part, with land administration; and the Afghan Cabinet adopted the National Policy on Internal Displaced People in 2013, recognizing the right of IDPs and returnees to adequate housing in urban areas, to secure tenure, and to settle in any part of the country. Despite these guidelines, it remains to be seen, what impact the policy will have.

\section{2.) Efforts of the National Assembly}

In 2012 a Special Commission was established by the Lower House to investigate landusurpation cases throughout the country. In 2013, a report was prepared listing names of land usurpers, but it was never made public.

The Complaint Hearing Commission of the Upper House plays an important role in hearing and addressing complaints concerning land usurpation. Officials of the Commission stated that numerous claims on land usurpation have been investigated and members of the commission had 9 provincial visits during the 2013 legislative year. One significant outcome of their efforts, in cooperation with other relevant organizations, was to restore 21,000 Jeribs of land in Khaja Alwan plain in Lagman province, thousands Jeribs of land in teachers' township in Herat, and unspecified amounts in Kabul, Nangarhar, Sar-pul, Balkh, and 
Bamyan. Members of the Commission questioned more than 400 government staff and have referred relevant issues to the AGO and to judicial bodies.

\section{3.) Government Bodies}

\section{a.) MAIL and ARAZI}

PD 45 mandated that MAIL collect precise information on the usurpation of private and government lands and to report to the Council of Ministers. Consequently, a commission led by MAIL was established to work on land usurpation. According to MAIL, the lack of law enforcement, population growth, insecurity, and the increasing cost of land are factors behind widespread land usurpation in urban and rural areas.

The commission has recovered and returned some government lands and, through 628 letters, introduced thousands of land usurpers to MOI, AGO, Department of Governmental Cases, HOO, and their provincial units to be prosecuted. However, there is little evidence that these cases have been proceeded significantly at these law-enforcement institutions.

ARAZI was primarily established within the structure of MAIL to address challenges with governmental lands and to act as the government entity leasing land to investors who require it for their business. Based on a minister's resolution in 2010, ARAZI merged with the General Department of Property and Land Affairs of MAIL and formed an independent organization. Currently, ARAZI is the central entity managing land affairs in Afghanistan, which provides service and information concerning land for citizens, institutions, and investors.

According to available data, ARAZI has identified about 1,279,708 Jeribs of usurped governmental lands, identifying 15,830 large, medium and small usurpers. Furthermore, it identified 355 illegal townships on $238,880.07$ Jeribs governmental lands.

ARAZI transferred 25,959.51 Jeribs governmental lands to the governmental organizations such as MOI, MoHE, MoPW, MoJ, MoM, MoF, NDS, Breshna Company, AISA, Local Governance and SAO. Moreover, ARAZI succeeded in restoring 472,894 Jeribs land before the end of 2013. The entity claims that it has sent 228 property related files to justice and judicial organization and addressed problems of 2,550 people.

\section{Challenges}

ARAZI faces a number of challenges in fulfilling its mandate. One of the most concerning is the lack of cooperation and misuse of power that seems to be forthcoming from the MOI, MOD, NDS, AGO, MOJ, and HOO. In addition, ARAZI has voiced complaints about the lack of cooperation and unlawful interference of governors. The Ministry of Urban Development also reportedly presents problems, as they build townships and projects before legally authorized.

ARAZI also faces challenges due to its apparently insufficient organizational structure and insecure work environment. It also lacks a sufficient budget and technical equipment to carry out its mandate. 


\section{b.) MOI, AGO, HOO}

Impunity and the lack of the rule of law contribute greatly to the land usurpation issue. MOI, tasked by PD 45, is responsible for collecting information concerning land usurpation. According to $\mathrm{MOI}$, the Directorate of Discovering Economic Crimes directed all subordinate units in the capital and in the provinces to present lists of usurped lands with the names of usurpers. A concise report provided by the Directorate of Discovering Economic Crimes indicates that, in total, 1,247,981 Jeribs of government and private lands have been usurped by 15,831 usurpers in 30 provinces.

The AGO is not responsible for investigating land-usurpation cases, as it is a civil matter. However, the AGO still gets involved, and has reportedly disseminated a circular to all its departments in the capital and in the provinces calling for comprehensive information concerning land usurpation. The AGO also reportedly sends its special investigation team to the provinces to investigate issues of land usurpation. But, overall, there have been very few achievements. Interviewees have argued that prosecutors lack strong support to protect them against influential individuals, often resulting in violence against prosecutors.

The Huquq Department deals with family, trade, and property disputes, but in 2012, 3,992 land related cases were referred to the Huquq Department ( $40 \%$ of all cases received by the Huquq Department), of which only $5 \%$ were resolved. According to officials, long administrative processes, interference from powerful individuals, and false documents hinder the effective resolution of land cases. In 2012, about 60 complex land cases were referred from the provinces to the Legal Rights Department for direction. According to figures presented by a Primary Court in Kabul, around 430 civil cases have been referred to courts in 2012. Files referred to the court were mainly sent by the Huquq Department and rarely by the AGO.

In 2013, 305 petitions and 1,319 files were referred to a District Legal Rights Office of Kabul province. Of these, $78 \%$ were referred by courts, however, $20 \%$ of the cases were processed by the AGO and then referred to Huquq, as well as $2 \%$ that were processed and referred by ANP.

$\mathrm{HOO}$ is also involved in land cases when an issue of administrative corruption is apparent, such as bribery, embezzlement, or the misuse of power. Authorities within $\mathrm{HOO}$, claim that they took some measures to fight land usurpation in cooperation with other organizations, but no report was ever shared about the nature of their practices and outcomes. After the issuance of PD 45, some $\mathrm{HOO}$ officials have indicated that the issue of land usurpation is the exclusive jurisdiction of ARAZI, and that, therefore, $\mathrm{HOO}$ has taken no part in activities concerning land usurpation.

\section{c.) Establishment of the Special Commission of Urban Properties and Townships Usurpation}

The Special Commission of Urban Properties and Townships Usurpation was established in June 2012, pursuant to a Presidential Decree to evaluate urban usurpation and to seek solutions. The commission is made up of six members led by the Senior Advisor to the President in Construction Affairs. The commission, after visiting 20 provinces, presented its report to the president with specific programs to implement the decree. First, the government 
shall conduct regular and extensive awareness campaigns to permanently resolve the process of public and private land usurpation. Second, a special penal code or amendment the current penal code is required to intensify punishments for land usurpers. Third, the government shall develop a policy for usurpers who return usurped lands within six months to be exempt from punishment. Fourth, steps shall be undertaken to develop a special policy for those who have bought properties from usurpers. Finally, the president shall issue a special legislative decree establishing a special administration to plan and implement the recommendations.

The plan also calls for an extensive public awareness campaign, the registration of private and governmental properties in an extensive computerized system, and special terms of reference shall be developed for usurpers who have grabbed small pieces of governmental properties to build shelter, which may include payment for the land in small installments. A mechanism will also be developed to ensure better coordination, a special court, and the establishment of a special department within the AGO to investigate land-usurpation cases.

\section{d.) Actions taken through Land Allocation Schemes (LAS)}

Over 630,000 Afghans are estimated to be internally displaced by ongoing conflict. Despite the informal settlements located in and around the major cities such as Kabul, Herat, and Mazar-e-Sharif, rapid urban growth has been fuelled by the reparation of refugees, the arrival of IDPs, and migration from rural areas. These factors all contribute to the government's need to deliver housing, land, and property rights.

IDPs often illegally occupy private or government land and they are sometimes threatened with eviction. Moreover, many IDPs have been excluded from government-sponsored Land Allocation Schemes, since identity documentation is required and IDPs are ineligible if they do not return to their original, often insecure, province of origin. Although many LAS projects exist on paper, very limited evidence of successful, sustainable relocation to LAS sites exists.

\section{4.) Actions taken by Civil Society Organizations}

There were only very small efforts put in place from CSOs in the fight against land usurpation in the past. However, there is the potential for CSOs to fight against land usurpation by putting pressure on the government, and particularly on the law enforcement actors, to take serious action. They can play vital role in making people aware of the problem and getting them together to act collectively against it. To date, though, CSOs have limited their focus to inquiries and reports on land usurpation.

\section{5.) Actions taken by the international community}

Since 2001, several international bodies have been engaged in implementing various programs and reforms in the agricultural sector. International assistance has, however, not been able to help the Afghan government create effective institutions and structures to tackle problems arising from land mismanagement. Instead, international assistance was mainly concerned with security problems, failing to recognize the wider negative effects land- and property related disputes have on the economic and political situation. 
Projects that have focused on land administration and management have attempted to strengthen the capacity of relevant institutions to manage land titling and registration in urban centers. Other projects focused on strengthening formal and informal dispute resolution procedures, as well as assisting the relevant authorities in their land allocation schemes projects. The international community also launched projects to reform and strengthens the judicial system and law enforcement agencies. Such efforts, however, have brought few tangible results. The institutions in charge of land administration and management still lack the required capacity and efficiency to provide effective mechanisms to uphold and guarantee ownership rights.

\section{6.) Role of media in the fight against land usurpation}

The media plays a vital role in the fight against corruption and land usurpation, including a role as whistleblowers. Accordingly, the media is well placed to inform people about land usurpers and usurped properties. Through reaching out to the public, the media can put pressure on the government to avoid the continuation of land usurpation. Furthermore, the media can put the government under pressure to implement strategies, recommendations, laws, and regulations to fight against land usurpation.

\section{Conclusion}

Several factors contribute to the problem of land usurpation in Afghanistan. Foundationally, land usurpation is facilitated by the lack of a comprehensive land survey and an effective registration system, as well as a weak legal framework for comprehensively dealing with land issues.

Land usurpation is also driven by insecurity. Armed conflict has weakened government administration and allowed powerful local figures to have extensive influence that often overshadows the authority of the government in some areas. Secondary effects of the violence, particularly the internal and external displacement of people, have had a large impact on the state's ability to administer land.

Although daunting, the challenges presented above are not insurmountable, though there has been a clear lack of political will to resolve these issues. In fact, government officials at all levels often contribute to the problem through fraud, forgery, bribery, or other corrupt practices. These practices result in usurpations of all sizes, from small pieces of land to large tracts. MEC's findings reveal that most private and government lands have been usurped by those who have, or had, a significant presence in the government.

In addition, there continues to be a lack of oversight and enforcement. Law enforcement agencies have been ineffective in investigating and prosecuting land usurpation. Even when the CSOs or the media take action, they are not encouraged, and there are many cases where legal and judicial organizations have detained or suspended broadcasts of media channels for exposing the facts. 


\section{Recommendations}

\begin{tabular}{|c|c|c|}
\hline No & Entities & Recommendations \\
\hline 1 & MOJ & $\begin{array}{l}\text { MoJ - in coordination with ARAZI, the Supreme Court, Kabul } \\
\text { Municipality, MOI, AGO, the Special Commission of the WJ, and other } \\
\text { related organizations - review the current draft laws on Usurpation } \\
\text { and Illegal Occupation of Government and Private Properties to } \\
\text { ensure that comprehensive land management laws are developed that } \\
\text { provides clear responsibility and streamlines the procedures for land } \\
\text { survey, registration, transfer, and dispute resolution. }\end{array}$ \\
\hline 2 & MOJ & $\begin{array}{l}\text { MOJ should give strong consideration to removing administrative } \\
\text { functions related to land transfers and registration from the purview of } \\
\text { courts and provide corresponding authority to ARAZI - or another } \\
\text { suitable organization - to allow the Courts to focus on adjudication. }\end{array}$ \\
\hline 3 & ARAZI & $\begin{array}{l}\text { ARAZI should develop and implement a plan to prioritize and survey } \\
\text { lands in Afghanistan as expeditiously as possible. This plan should } \\
\text { include the reinitiation of land clearance efforts to categorize and } \\
\text { differentiate government and private lands. }\end{array}$ \\
\hline 4 & MoHRA & $\begin{array}{l}\text { MoHRA should survey and verify endowed lands with the support of } \\
\text { government instituions, ensuring that all supporting documents are } \\
\text { registered and archived. }\end{array}$ \\
\hline 5 & $\begin{array}{l}\text { ARAZI, } \\
\text { MoRR, } \\
\text { MoHRA, } \\
\text { Kabul } \\
\text { Municipality, } \\
\text { and Makhzan }\end{array}$ & $\begin{array}{l}\text { Land authorities, including ARAZI, MoRR, MoHRA, Kabul Municipality, } \\
\text { and Makhzan, should utilize a consolidated electronic system for the } \\
\text { registration and transfer of lands. Until such time, immediate measures } \\
\text { should be taken to better secure land registries across the country } \\
\text { against natural deterioration or illegal modification. }\end{array}$ \\
\hline 6 & MoJ & $\begin{array}{l}\text { MoJ should send the Property Dealer Regulation Law to the Council of } \\
\text { Ministers for approval expeditiously. In the interim, municipalities } \\
\text { should take measures to review and punish malfeasance perpetrated } \\
\text { by property dealers and land brokers. }\end{array}$ \\
\hline 7 & $\begin{array}{l}\text { Supreme } \\
\text { Court and } \\
\text { ARAZI }\end{array}$ & $\begin{array}{l}\text { The Supreme Court and ARAZI should establish a committee } \\
\text { comprised of relevant organizations to review the various deeds } \\
\text { currently in use and to develop a comprehensive deed suitable for all } \\
\text { purposes. }\end{array}$ \\
\hline 8 & $\begin{array}{l}\text { Courts, } \\
\text { ARAZI, } \\
\text { Municipalities }\end{array}$ & $\begin{array}{l}\text { Land related institutions, especially courts, ARAZI, and municipalities, } \\
\text { should identify and acquire technological solutions that allow it to } \\
\text { better detect forged and falsified documents. }\end{array}$ \\
\hline 9 & $\begin{array}{c}\text { ARAZI, MOI, } \\
\text { AGO }\end{array}$ & $\begin{array}{l}\text { ARAZI, MOI, AGO, and the Courts should establish case management } \\
\text { protocols and committees to better coordinate efforts and to ensure } \\
\text { that land cases are better investigated, prosecuted, and tracked. }\end{array}$ \\
\hline
\end{tabular}




\begin{tabular}{|c|c|c|}
\hline 10 & $\begin{array}{l}\text { Supreme } \\
\text { Court }\end{array}$ & $\begin{array}{l}\text { The Supreme Court should develop detailed procedures and direction } \\
\text { for courts to follow when adjudicating land cases that are not } \\
\text { supported by documents and records. }\end{array}$ \\
\hline 11 & AGO, MOI & $\begin{array}{l}\text { Mol and AGO should stop inappropriately interfering in dispute } \\
\text { resolution processes and should refer civil cases to the MOJ without } \\
\text { investigation. }\end{array}$ \\
\hline 12 & $\mathrm{MOI}$ & $\begin{array}{l}\text { MOI should enhance efforts to protect government lands, to assist in } \\
\text { investigations, to assure that defendats appear in court, and to enforce } \\
\text { court orders, regardless of the identity of the parties to the dispute. }\end{array}$ \\
\hline 13 & ANP / MOI & $\begin{array}{l}\text { The ANP and Courts should receive enhanced training regarding land } \\
\text { laws and procedures. }\end{array}$ \\
\hline 14 & ARAZI & $\begin{array}{l}\text { ARAZI should expand the financial and human resources of their } \\
\text { provincial units. }\end{array}$ \\
\hline 15 & $\begin{array}{l}\text { Government } \\
\text { Officials }\end{array}$ & $\begin{array}{l}\text { Ministers and governors should stop issuing unlawful orders and } \\
\text { decrees in regard to distributing lands for specific and non-eligible } \\
\text { people. }\end{array}$ \\
\hline 16 & MoHRA & $\begin{array}{l}\text { MoHRA, with support from ARAZI and MoIC, should start a } \\
\text { widespread religious campaign against land usurpation through the } \\
\text { Mullas and mosques. }\end{array}$ \\
\hline 17 & MoUD & $\begin{array}{l}\text { MoUD should develop a long-term strategy for resolving the shortage } \\
\text { of housing for improverished individuals. Short-term measures should } \\
\text { be implemented in the interim to ensure that homeless are provided } \\
\text { with shelter. }\end{array}$ \\
\hline 18 & MoF & $\begin{array}{l}\text { MoF should reassign Mustafiat as responsible entity for the tax } \\
\text { collecting process in the land transfer procedure as different entities } \\
\text { are dealing with taxes provinces and in Kabul (Mustafiat in the } \\
\text { provinces and Revenue Department in Kabul) }\end{array}$ \\
\hline
\end{tabular}




\section{Annex I: Terms of Reference for the Report on the Public Inquiry on Land Usurpation}

WHEREAS, the issue of land usurpation in Afghanistan has negatively affected the economy and all of Afghan society, including the lives of individuals who have been deprived of land and the benefits of ownership;

WHEREAS, the General Directorate of Afghanistan Land Authority (ARAZI) have highlighted that more than 1,2 million Jeribs of land has been usurped across Afghanistan over the last 30 years;

WHEREAS, the involvement of powerful and high ranking officials, among others, has been identified as playing a central in land usurpation;

WHEREAS, the Government of the Islamic Republic of Afghanistan has attempted to address land usurpation through the National Strategy of Administrative Reform and AntiCorruption and the creation of ARAZI as the central body to rectify these issues;

WHEREAS, ARAZI has registered some success in identifying the scope of the problem, but has not been able to implement effective strategies and there are significant outstanding concerns from members of the national and international communities;

WHEREAS, there is a need to independently collect and review all information related to the land usurpation issue for the purpose of informing the public, the government, and the international community, about the causes and contributing factors and to develop effective recommendations to address the problem;

WHEREAS, the Independent Joint Anti-Corruption Monitoring and Evaluation Committee (the Committee) was established by the international community and the Government as an independent body mandated to monitor and evaluate the Government and the international community's efforts to combat corruption;

THEREFORE, pursuant to the authority contained in the Committee's terms of reference:

\section{Establishment of the Public Inquiry}

1. The Committee will conduct an in-depth public inquiry in an expeditious manner and will deliver its final report and recommendations to the Government, the international community and the public.

\section{Mandate}

2. The Committee will inquire into:

a. The structural framework for - and the administration of - the management, distribution and verification of lands in Afghanistan;

b. The administrative and legal responses to illicit activities, including the prosecution and punishment for misappropriating land;

c. The identity of usurpers and the scope of their activities;

d. The scope and nature of the involvement of international forces in land usurpation issues;

e. The impact of land usurpation on vulnerable groups, including women and displaced persons; and

f. Mechanisms to ensure that impoverished individuals currently occupying government lands illegally are fairly treated are not further marginalized. 
In order to increase public awareness and transparency; and to make recommendations to resolve land usurpation issues.

3. In its report the Committee will not assign any form or level of guilt on any individual.

\section{Procedures}

4. The Committee may:
a. conduct research and collect information, including interviews;
b. consult, in private or in public, with persons or groups; and
c. receive oral and written submissions.

5. The Committee will review and consider any relevant records or reports; and will rely wherever possible on existing reports and written statements submitted to the Committee. The Committee may consider such reports and records instead of conducting interviews.

6. The Committee will determine whether a person or institution can participate in the public inquiry and the manner and scope of that participation.

7. The Committee will rely wherever possible on representatives of institutions and will rely on representative organizations to represent the public interest, or the perspective of civil society.

8. The Committee may give directions necessary for the inquiry and may invite a person or a representative of an institution to,

a. attend the public inquiry to provide information; and

b. produce any information, document or object under the person or intuition's control.

9. The Committee will ensure that the report is available in Dari, Pashto, and English.

\section{Resources}

10. The Committee's Secretariat will provide support for the implementation of the inquiry and may retain such experts or staff it considers necessary to perform its duties.

11. The Committee will use all legal means in conducting the inquiry to promote accessibility and transparency.

12. Afghan ministries, agencies, boards, commissions and independent institutions and the international community are invited to assist the Committee to the fullest extent so that the Committee may carry out this inquiry. 


\section{Annex II: Sources Considered by the Committee}

\begin{tabular}{|c|c|}
\hline No & A. Laws \\
\hline 1 & Afghanistan Constitution \\
\hline 2 & Afghanistan Civil Law \\
\hline 3 & Civil Procedure Law \\
\hline 4 & Penal Code \\
\hline 5 & The Government Cases Law \\
\hline 6 & Law on Obtaining Rights \\
\hline 7 & Decree of the President of the Transitional Islamic State of Afghanistan on Property \\
\hline 8 & Municipality Law \\
\hline 9 & $\begin{array}{l}\text { Regulation for distribution and sale of residential, commercial and high-rise public building in } \\
\text { Kabul city }\end{array}$ \\
\hline 10 & Land Acquisition Law \\
\hline 11 & Law on Regulating Land Affairs \\
\hline 12 & Law on Organization and Jurisdiction of Courts of the Islamic Republic of Afghanistan \\
\hline 13 & Law on Oversight Strategy in the Fight against Administrative Corruption \\
\hline 14 & $\begin{array}{l}\text { Presidential Decree of the Transitional Islamic State of Afghanistan in the establishment of } \\
\text { special courts to settle property disputes (2003) }\end{array}$ \\
\hline 15 & Presidential Decree No. 45 \\
\hline 16 & Law on Cadastral Survey \\
\hline 17 & Presidential Decree No. 104 in relation to the distribution of land to returnees \\
\hline 18 & Constitution of 1987 (Najibullah era) \\
\hline 19 & Regulation on Legal Aids \\
\hline 20 & Law on the Transfer and Exchange of Land \\
\hline 21 & Leasing procedures \\
\hline 22 & $\begin{array}{l}\text { Draft proposals addressing public and private lands usurped in the country (provided by } \\
\text { ARAZI) }\end{array}$ \\
\hline \multirow[t]{2}{*}{23} & $\begin{array}{l}\text { Report of the Independent Directorate of Lands to the National Assembly (the mechanism to } \\
\text { present an annual report to the National Assembly) }\end{array}$ \\
\hline & B. Research Reports \\
\hline 24 & Report on "Land, People and government in Afghanistan", published by AREU \\
\hline 25 & Report on "Land Management in Limbo " published by AREU \\
\hline 26 & $\begin{array}{l}\text { Report on " Land Rights in Crisis: Restoring Property Immunity in Afghanistan " published by } \\
\text { AREU }\end{array}$ \\
\hline 27 & $\begin{array}{l}\text { Report on" Land Conflict in Afghanistan: Building Capacity to Eliminate Vulnerabilities" } \\
\text { published by AREU }\end{array}$ \\
\hline 28 & MEC Recommendations and Benchmarks. \\
\hline 29 & MEC's report on conducting "VCA in land distribution in MoRR" \\
\hline 30 & $\begin{array}{l}\text { Brief report of the Special Committee of the Wolesi Jirga on monitoring the government's } \\
\text { performances }\end{array}$ \\
\hline 31 & Report from the Commission on Reviewing City Property Usurped \\
\hline 32 & Ministry of Refugees report on the implementation the Presidential Decree No. 45 \\
\hline 33 & MOl's report on the implementation of Presidential Decree No. 45 \\
\hline 34 & AGO's report on land usurpation in Nangarhar \\
\hline \multirow[t]{2}{*}{35} & AGO's report on public properties usurped in Paghman district of Kabul province \\
\hline & C. Reports on land usurpation cases published on these sites: \\
\hline 36 & Hasht Subh newspaper (www.8am.af) \\
\hline 37 & The BBC 's Persian website (www.bbcpersian.com) \\
\hline 38 & Klid Group website (www.tkg.af) \\
\hline 39 & Tolo News website (www.tolonews.com) \\
\hline 40 & Doing Business website (www.doingbusiness.org) \\
\hline 41 & AREU website (www.areu.org.af) \\
\hline 42 & Jamhoor News Agency (www.jomhornews.com) \\
\hline 43 & Bukhdy news website (www.bokhdinews.af) \\
\hline 44 & The Open Community newspaper (www.dailyopensociety.com) \\
\hline
\end{tabular}




\begin{tabular}{|l|l|}
\hline & D. Interviews \\
\hline 45 & Employees and officials of Kabul Municipality \\
\hline 46 & Visitors of Kabul Municipality \\
\hline 47 & Staff of districts of Kabul Municipality \\
\hline 48 & Staff of Mistofiat (state accountancy) \\
\hline 49 & Employees of the General Directorate of Revenue (Central Zone) \\
\hline 50 & Officials and employees of the Ministry of Interior Affairs \\
\hline 51 & Visitors of Kabul City Court \\
\hline 52 & Visitors of the Primary Court \\
\hline 53 & Staff of the Government Cases Department (Kabul) \\
\hline 54 & The Department of Rights of the MOJ \\
\hline 55 & Staff of the Department of Geodesy and Cartography \\
\hline 56 & Staff of the Afghan Independent Directorate of Land (ARAZI) \\
\hline 57 & IDLG staff \\
\hline 58 & MoRR Staff \\
\hline 59 & AGO staff \\
\hline 60 & HOO staff \\
\hline 61 & Independent journalists \\
\hline 62 & $\begin{array}{l}\text { Members of the Special Committee of Wolesi Jirga on monitoring the government's } \\
\text { performance }\end{array}$ \\
\hline 63 & Member of Upper House Complaints Commission \\
\hline 64 & Numerous Civil Society activists \\
\hline 65 & Media officials and activists \\
\hline 66 & Harakat \\
\hline 67 & USAID staff \\
\hline 68 & UNHCR employees \\
\hline 69 & NRC employees \\
\hline & D. Interviews with offices in the provinces of Herat, Nangarhar and Balkh including: \\
\hline 70 & Directorate of Land Employees \\
\hline 71 & Municipality staff \\
\hline 72 & AGO Staff \\
\hline 73 & Court of Appeals City Court of these three provinces \\
\hline
\end{tabular}




\section{Annex III: Data on Usurped Land in Afghanistan}

\section{1.) Table of illegal townships and residential areas}

\begin{tabular}{|l|l|l|l|}
\hline \multicolumn{4}{|l|}{ Table of illegal townships and residential areas } \\
\hline No & $\begin{array}{l}\text { Location of } \\
\text { Township }\end{array}$ & $\begin{array}{l}\text { Number of } \\
\text { townships }\end{array}$ & Usurped lands in Jerib \\
\hline 1 & Balkh & 71 & 54,943 \\
\hline 2 & Kabul & 23 & 19,600 \\
\hline 3 & Herat & 5 & 3,000 \\
\hline 4 & Nangarhar & 123 & 145,167 \\
\hline 5 & Parwan & 3 & 1,100 \\
\hline 6 & Ghazni & 2 & 7,000 \\
\hline Total & & 228 & 230,810 \\
\hline
\end{tabular}

2.) Land usurped by government organisations according to provinces

\begin{tabular}{|l|l|l|l|}
\hline \multicolumn{4}{|l|}{ Land usurped by government organisations according to provinces } \\
\hline No & Province & Usurped land in Jerib & Number of usurper organizations \\
\hline 1 & Balkh & 11,960 & 47 \\
\hline 2 & Kabul & 1,414 & 7 \\
\hline 3 & Kunduz & 1,106 & 3 \\
\hline 4 & Nangarhar & 4,525 & 2 \\
\hline 5 & Kapisa & 36 & 14 \\
\hline 6 & Paktia & 574 & 12 \\
\hline 7 & Khost & 854 & 3 \\
\hline 8 & Baghlan & 6,000 & 3 \\
\hline 9 & Takhar & 52 & 8 \\
\hline 10 & Kunar & 3 & 6 \\
\hline 11 & Parwan & 2,012 & 24 \\
\hline 12 & Zabul & 1 & 1 \\
\hline 13 & Nengarhar & 292 & 8 \\
\hline 14 & Uruzgan & 2,000 & 1 \\
\hline Total & 30,829 & 139 \\
\hline
\end{tabular}

3.) Usurped governmental lands across the country

\begin{tabular}{|l|l|l|l|l|l|l|}
\hline \multicolumn{6}{|c|}{ Usurped governmental lands across the country (in Jeribs) } \\
\hline No & Province & $\begin{array}{c}\text { Usurped } \\
\text { Land }\end{array}$ & $\begin{array}{c}\text { Restored } \\
\text { Land (up to } \\
2012)\end{array}$ & $\begin{array}{c}\text { Number } \\
\text { of } \\
\text { usurpers }\end{array}$ & $\begin{array}{c}\text { Highest } \\
\text { rate of } \\
\text { Usurpation }\end{array}$ & $\begin{array}{c}\text { Lowest Rate of } \\
\text { Usurpation }\end{array}$ \\
\hline 1 & Balkh & 194,756 & 91,241 & 901 & 35,000 & Less than 1 Jerib \\
\hline 2 & Nimroz & 138,719 & 97,574 & 1,168 & 47,000 & Less than 1 Jerib \\
\hline 3 & Helmand & 125,400 & 1,940 & 36 & 95,000 & 100 \\
\hline 4 & Sar-e-Pul & 80,313 & 1,192 & 568 & 700 & 2 \\
\hline 5 & Herat & 70,698 & 65,396 & 626 & 6,769 & Less than 1 Jerib \\
\hline 6 & Khost & 45,295 & 47,272 & 56 & 14,990 & 1 \\
\hline
\end{tabular}




\begin{tabular}{|l|l|l|l|l|l|l|}
\hline 7 & Takhar & 44,726 & 206 & 1,647 & 15,000 & Less than 1 Jerib \\
\hline 8 & Samangan & 33,339 & 40,037 & 633 & 1,400 & 2 \\
\hline 9 & Baghlan & 33,002 & 50,262 & 1,812 & 3,000 & Less than 1 Jerib \\
\hline 10 & Nengarhar & 30,584 & 9,230 & 740 & 10,000 & Less than 1 Jerib \\
\hline 11 & Uruzgan & 27,587 & 0 & 13 & 15,874 & 1 \\
\hline 12 & Kabul & 25,990 & 23,284 & 212 & 4,245 & 1 \\
\hline 13 & Badghis & 23,495 & 500 & 59 & 10,000 & 1 \\
\hline 14 & Ghazni & 19,566 & 3,280 & 132 & 5,000 & 1 \\
\hline 15 & Logar & 16,639 & 2,650 & 1,126 & 4,080 & Less than 1 Jerib \\
\hline 16 & Jowzjan & 10,444 & 1,074 & 473 & 1,401 & Less than 1 Jerib \\
\hline 17 & Farah & 8,719 & 0 & 117 & 3,000 & Less than 1 Jerib \\
\hline 18 & Kunduz & 7,792 & 1,900 & 965 & 1,200 & Less than 1 Jerib \\
\hline 19 & Faryab & 7,082 & 1,121 & 204 & 160 & Less than 1 Jerib \\
\hline 20 & Zabul & 6,793 & 0 & 271 & 1,500 & Less than 1 Jerib \\
\hline 21 & Kunar & 6,131 & 0 & 469 & 750 & Less than 1 Jerib \\
\hline 22 & Paktia & 5,800 & 5,046 & 16 & 2,000 & 3 \\
\hline 23 & Wardak & 5,324 & 2,816 & 287 & 214 & 1 \\
\hline 24 & Parwan & 4,945 & 4,365 & 167 & 500 & 1 \\
\hline 25 & Directorate & 4,489 & no data. & 888 & 2,000 & Less than 1 Jerib \\
& Nengarhar & & & & & \\
\hline & Channel & & & 148 & 600 & 5 \\
\hline 26 & Badakhshan & 3,210 & 600 & 69 & 200 & 1 \\
\hline 27 & Kandahar & 2,215 & No data & 1,473 & 9 & Less than 1 Jerib \\
\hline 28 & Kapisa & 1,464 & 0 & 37 & 976 & Less than 1 Jerib \\
\hline 29 & Bamyan & 1,393 & 238 & 518 & 34 & Less than 1 Jerib \\
\hline 30 & Laghman & 424 & 34 & 15,831 & & \\
\hline Country Total & 986,334 & 451,158 & & & \\
\hline
\end{tabular}

Data was provided by ARAZI 2013/2014 